\title{
Comparison of iron and copper doped manganese cobalt spinel oxides as protective coatings for solid oxide fuel cell interconnects
}

Talic, Belma; Molin, Sebastian; Wiik, Kjell; Hendriksen, Peter Vang; Lein, Hilde Lea

Published in:

Journal of Power Sources

Link to article, DOI:

10.1016/j.jpowsour.2017.10.060

Publication date:

2017

Document Version

Peer reviewed version

Link back to DTU Orbit

Citation (APA):

Talic, B., Molin, S., Wiik, K., Hendriksen, P. V., \& Lein, H. L. (2017). Comparison of iron and copper doped manganese cobalt spinel oxides as protective coatings for solid oxide fuel cell interconnects. Journal of Power Sources, 372, 145-156. https://doi.org/10.1016/j.jpowsour.2017.10.060

\section{General rights}

Copyright and moral rights for the publications made accessible in the public portal are retained by the authors and/or other copyright owners and it is a condition of accessing publications that users recognise and abide by the legal requirements associated with these rights.

- Users may download and print one copy of any publication from the public portal for the purpose of private study or research.

- You may not further distribute the material or use it for any profit-making activity or commercial gain

- You may freely distribute the URL identifying the publication in the public portal 


\title{
Comparison of iron and copper doped manganese cobalt spinel oxides as protective coatings for solid oxide fuel cell interconnects
}

\author{
Belma Talic ${ }^{\mathrm{a}, \mathrm{b}, *}$ (beltal@dtu.dk), Sebastian Molin ${ }^{\mathrm{b}}$, Kjell Wiik ${ }^{\mathrm{a}}$, Peter Vang Hendriksen ${ }^{\mathrm{b}}$ \\ Hilde Lea Lein ${ }^{a}$ (hilde.lea.lein@ntnu.no) \\ ${ }^{a}$ Department of Materials Science and Engineering, Norwegian University of Science and Technology, Sem \\ Sælands Vei 12, 7491 Trondheim, Norway \\ 'Department of Energy Conversion and Storage, Technical University of Denmark, DTU Ris $\emptyset$ Campus, \\ Frederiksborgvej 399, DK-4000 Roskilde, Denmark \\ *Corresponding author
}

\begin{abstract}
MnCo}_{2} \mathrm{O}_{4}, \mathrm{MnCo}_{1.7} \mathrm{Cu}_{0.3} \mathrm{O}_{4}$ and $\mathrm{MnCo}_{1.7} \mathrm{Fe}_{0.3} \mathrm{O}_{4}$ are investigated as coatings for corrosion protection of metallic interconnects in solid oxide fuel cell stacks. Electrophoretic deposition is used to deposit the coatings on Crofer 22 APU alloy. All three coating materials reduce the parabolic oxidation rate in air at $900{ }^{\circ} \mathrm{C}$ and $800{ }^{\circ} \mathrm{C}$. At $700{ }^{\circ} \mathrm{C}$ there is no significant difference in oxidation rate between coated samples and uncoated pre-oxidized Crofer 22 APU. The cross-scale area specific resistance (ASR) is measured in air at $800{ }^{\circ} \mathrm{C}$ using $\mathrm{La}_{0.85} \mathrm{Sr}_{0.1} \mathrm{Mn}_{1.1} \mathrm{O}_{3}$ (LSM) contact plates to simulate the interaction with the cathode in a SOFC stack. All coated samples have three times lower ASR than uncoated Crofer $22 \mathrm{APU}$ after $4370 \mathrm{~h}$ aging. The ASR increase with time is lowest with the $\mathrm{MnCo}_{2} \mathrm{O}_{4}$ coating, followed by the $\mathrm{MnCo}_{1.7} \mathrm{Fe}_{0.3} \mathrm{O}_{4}$ and $\mathrm{MnCo}_{1.7} \mathrm{Cu}_{0.3} \mathrm{O}_{4}$ coatings. LSM plates contacted to uncoated Crofer 22 APU contain significant amounts of $\mathrm{Cr}$ after aging, while all three coatings effectively prevent Cr diffusion into the LSM. A complex Cr-rich reaction layer develops at the coating-alloy interface during oxidation. $\mathrm{Cu}$ and $\mathrm{Fe}$ doping reduce the extent of this reaction layer at $900{ }^{\circ} \mathrm{C}$, while at $800{ }^{\circ} \mathrm{C}$ the effect of doping is insignificant.
\end{abstract}

Keywords: Solid Oxide Fuel Cell, Metallic Interconnect, Manganese Cobalt Spinel, Coating, High Temperature Oxidation, Area Specific Resistance

\section{Introduction}

Solid oxide fuel cells (SOFC) are electrochemical devices that can covert the chemical energy of fuels such as $\mathrm{H}_{2}, \mathrm{CH}_{4}$ or $\mathrm{CO}$ to electrical energy at a high electrical efficiency. More than 10000 domestic SOFC units are currently in operation in Japan [1], but high costs and a limited lifetime are impeding more widespread commercialization of the technology. One of the lifetime-limiting challenges is degradation of the ferritic stainless steel (FSS) used as the interconnect material [2,3]. Under SOFC operating conditions the FSS oxidizes, forming a several $\mu \mathrm{m}$ thick $\mathrm{Cr}_{2} \mathrm{O}_{3}$ and $(\mathrm{Mn}, \mathrm{Cr})_{3} \mathrm{O}_{4}$ scale on the surface. Because of the modest electrical conductivity of these oxides the resistance through a SOFC stack increases with time as the scale thickens, leading to a decrease in the power output [4].

Furthermore, the oxide scale is prone to form volatile $\mathrm{Cr}(\mathrm{VI})$-species, that have been shown to degrade the SOFC cathode performance [5,6].

A way to mitigate these adverse effects is to coat the FSS with a protective, electrically conductive material. $(\mathrm{Mn}, \mathrm{Co})_{3} \mathrm{O}_{4}$ spinels are considered promising coating materials for the air side of 
the interconnect, demonstrated to reduce both the area specific resistance (ASR) across the interconnect [7,8] and the rate of Cr-evaporation [9]. The most extensively investigated compositions in this system are $\mathrm{MnCo}_{2} \mathrm{O}_{4}$ and $\mathrm{Mn}_{1.5} \mathrm{Co}_{1.5} \mathrm{O}_{4}$. The former is a cubic spinel, while the latter is a dual phase mixture of cubic $\mathrm{MnCo}_{2} \mathrm{O}_{4}$ and tetragonal $\mathrm{Mn}_{2} \mathrm{CoO}_{4}$ that transform into a single phase cubic spinel above ca.

$400{ }^{\circ} \mathrm{C}[10,11]$. Both materials have appreciable electrical conductivity $\left(60-90 \mathrm{~S} \mathrm{~cm}^{-1}\right.$ at $800{ }^{\circ} \mathrm{C}$ $[11,12])$ and an acceptable thermal expansion coefficient (TEC) $\left(11.4-14.4 \times 10^{-6} \mathrm{~K}^{-1}\right.$ between $25^{\circ} \mathrm{C}$ and $\left.800{ }^{\circ} \mathrm{C}[13-15]\right)$. Attempts to improve the $(\mathrm{Mn}, \mathrm{Co})_{3} \mathrm{O}_{4}$ coating material by substituting some of the $\mathrm{Co}$ with $\mathrm{Fe}$ or $\mathrm{Cu}$ have been reported [13,16-21]. The TEC of $\mathrm{MnCo}_{2} \mathrm{O}_{4}$ is reduced by replacing some of the Co with $\mathrm{Fe}$, which in some cases may be advantageous depending on what type of cell the interconnect is connected to [15]. Although Fe-doping also reduces the electrical conductivity, the conductivity measured for $\mathrm{MnCo}_{1.7} \mathrm{Fe}_{0.3} \mathrm{O}_{4}$ at $800{ }^{\circ} \mathrm{C}\left(47 \mathrm{~S} \mathrm{~cm}^{-1}\right)$ is still several orders of magnitude higher than the typically reported electrical conductivity of $\mathrm{Cr}_{2} \mathrm{O}_{3}\left(0.1-0.01 \mathrm{~S} \mathrm{~cm}^{-1}\right)[22,23]$. Substituting $\mathrm{Co}$ with $\mathrm{Cu}$ improves the electrical conductivity [15] and has been suggested to enhance densification of the coating [17]. Furthermore, diffusion couple studies indicate that both $\mathrm{Cu}$ and $\mathrm{Fe}$ substitution may be beneficial for reducing the formation of a moderately conductive $\mathrm{Cr}$-rich $(\mathrm{Mn}, \mathrm{Co}, \mathrm{Cr})_{3} \mathrm{O}_{4}$ reaction layer at the interface between the spinel coating and the thermally grown oxide scale [24,25]. The electrical conductivity of spinel oxides generally decreases with increasing $\mathrm{Cr}$ content and in case of $\mathrm{Mn}_{0.5} \mathrm{Co}_{0.5} \mathrm{Cr}_{2} \mathrm{O}_{4}$ the electrical conductivity at $800{ }^{\circ} \mathrm{C}$ is only $0.007 \mathrm{~S} \mathrm{~cm}^{-1}[12,26]$. Excessive growth of a Cr-rich $(\mathrm{Mn}, \mathrm{Co}, \mathrm{Cr})_{3} \mathrm{O}_{4}$ reaction layer may therefore be negative for the interconnect ASR.

Most studies of the oxidation resistance and ASR of FSS coated with $\mathrm{Fe}$ and $\mathrm{Cu}$ doped $(\mathrm{Mn}, \mathrm{Co})_{3} \mathrm{O}_{4}$ are limited to relatively short exposure times $(<500 \mathrm{~h})$ and do not provided a detailed investigation of the interaction between the coating and the FSS [16,17,27-30]. Furthermore, since the ASR has been measured using different set-ups and contact electrodes, it is difficult to compare the performance of the different coating materials and thus evaluate whether $\mathrm{Fe}$ or $\mathrm{Cu}$ doping offers any benefit.

In this work, we investigate the long-term $(4000 \mathrm{~h})$ oxidation behavior and cross-scale ASR of $\mathrm{MnCo}_{2} \mathrm{O}_{4}, \mathrm{MnCo}_{1.7} \mathrm{Fe}_{0.3} \mathrm{O}_{4}$ and $\mathrm{MnCo}_{1.7} \mathrm{Cu}_{0.3} \mathrm{O}_{4}$ coated Crofer 22 APU. The consequences of forming $\mathrm{Cr}$-rich reaction layers between the interconnect and these spinel coatings are further discussed.

\section{Experimental}

\subsection{Sample preparation}

A $1 \mathrm{~mm}$ thick plate of Crofer 22 APU (Thyssen Krupp) with the composition given in Table 1 was cut into $20 \times 20 \mathrm{~mm}$ coupons. A $3 \mathrm{~mm}$ hole was drilled in one of the corners to allow for hanging in the oxidation furnace. The coupons were ground with SiC-paper, polished down to $1 \mu \mathrm{m}$ using diamond abrasive, and cleaned in acetone and ethanol for $10 \mathrm{~min}$ each in an ultrasonic bath.

Table 1. Composition of Crofer 22 APU alloy used in this study in wt.\%. Analyzed by Optical Emission Spectroscopy at Force Technology, Denmark.

\begin{tabular}{lcccccccc}
\hline Alloy & $\mathrm{Fe}$ & $\mathrm{Cr}$ & $\mathrm{Mn}$ & $\mathrm{Ti}$ & $\mathrm{La}$ & $\mathrm{C}$ & $\mathrm{Si}$ & $\mathrm{Al}$ \\
\hline Crofer 22 APU & Bal. & 23 & 0.42 & 0.068 & $0.04-0.20^{1}$ & 0.003 & $0.049^{2}$ & 0.007 \\
\hline
\end{tabular}

${ }^{1}$ La was not measured by OES. Typical concentration according to manufacturer's datasheet

${ }^{2}$ Determination of Si content by OES is associated with large uncertainty 
$\mathrm{MnCo}_{2} \mathrm{O}_{4}(\mathrm{MC}), \mathrm{MnCo}_{1.7} \mathrm{Fe}_{0.3} \mathrm{O}_{4}(\mathrm{MCFe})$ and $\mathrm{MnCo}_{1.7} \mathrm{Cu}_{0.3} \mathrm{O}_{4}(\mathrm{MCCu})$ spinel powders were prepared by spray pyrolysis of aqueous based nitrate solutions as described in detail elsewhere [15]. The powders were calcined at $650{ }^{\circ} \mathrm{C}$ for $10 \mathrm{~h}$ in air, ball milled overnight in ethanol (Ø $10 \mathrm{~mm}$ YSZ milling balls), dried in a rotary evaporator, and sieved at $250 \mu \mathrm{m}$. The particle size of as-prepared powders was characterized using a Beckman coulter I/S particle size analyzer. Small amounts of each powder were dispersed in ethanol by ultrasonication before analysis. All powders had a bimodal particle size distribution, with median sizes $\left(\mathrm{d}_{50}\right)$ equal to $0.70 \mu \mathrm{m}$ for MC, $0.63 \mu \mathrm{m}$ for MCFe and $1.22 \mu \mathrm{m} \mathrm{MCCu}$.

Electrophoretic deposition (EPD) was used to coat the Crofer 22 APU coupons with the spinel powders. The EPD set-up consisted of a $150 \mathrm{ml}$ Teflon box and two $4 \times 4 \mathrm{~cm}$ plates of Crofer 22 APU serving as counter electrodes. Suspensions were made by ball milling $5 \mathrm{wt} . \%$ of powder in a $50 / 50$ vol.\% mixture of isopropanol and ethanol for 2 days (Ø $10 \mathrm{~mm} \mathrm{YSZ} \mathrm{milling} \mathrm{balls,} 500 \mathrm{ml}$ PEbottles). The steel coupon was connected to the negative terminal and mounted in parallel between the counter electrodes at a distance of $15 \mathrm{~mm}$. Deposition was carried out at $35 \mathrm{~V}$ for $40-100 \mathrm{~s}$. After drying in room temperature, the coated samples were heat treated in a tubular furnace at $900{ }^{\circ} \mathrm{C}$ for $2 \mathrm{~h}$ in $\mathrm{N}_{2-}$ $9 \% \mathrm{H}_{2}$, followed by $2 \mathrm{~h}$ at $800{ }^{\circ} \mathrm{C}$ in air. The heating and cooling rates were $120^{\circ} \mathrm{C} \mathrm{h}^{-1}$. Gasses were bubbled through water at $5{ }^{\circ} \mathrm{C}$ to give a moisture content of ca. $1 \%$. Uncoated Crofer 22 APU was preoxidized under the same conditions to serve as a reference.

\subsection{Characterization}

The oxidation kinetics of spinel coated and bare pre-oxidized Crofer 22 APU were studied in air at $700{ }^{\circ} \mathrm{C}, 800{ }^{\circ} \mathrm{C}$ and $900{ }^{\circ} \mathrm{C}$ in a chamber furnace. There was no forced airflow to the furnace (i.e. nearly stagnant conditions). Three to five samples of each type were suspended vertically in the furnace. Every $250 \mathrm{~h}$, the furnace was cooled to room temperature $\left(180^{\circ} \mathrm{C} \mathrm{h}^{-1}\right)$ and the mass gain was determined by weighing the samples on a scale with $0.00001 \mathrm{~g}$ accuracy (XS205 Mettler Toledo). The coated and uncoated samples were oxidized separately to avoid any $\mathrm{Cr}(\mathrm{VI})(\mathrm{g})$ from the uncoated samples depositing on the coated samples.

The cross-scale/coating area specific resistance (ASR) was characterized in air using the set-up illustrated in Figure 1, described in detail in [31]. For the ASR measurement, Crofer 22 APU was cut into $20 \times 40 \mathrm{~mm}$ coupons and two $6 \mathrm{~mm}$ holes were drilled in the shorter ends for mounting purposes. Platinum wire (Ø $0.3 \mathrm{~mm}$ ) was flattened on one end and welded to each coupon along the shorter edge. The spinel coatings were subsequently deposited and sintered as described above. Porous $\mathrm{La}_{0.85} \mathrm{Sr}_{0.1} \mathrm{Mn}_{1.1} \mathrm{O}_{3}(\mathrm{LSM})(20 \times 20 \times 1 \mathrm{~mm})$ plates spray coated with a $50-60 \mu \mathrm{m}$ layer of LSM $(89 \mathrm{wt} . \%)$ and $\mathrm{Co}_{3} \mathrm{O}_{4}(11 \mathrm{wt} . \%)$ slurry mixture were used as contacting plates. The LSM plates were stacked between the steel samples as illustrated in Figure 1. Gold foil $(0.3 \mathrm{~mm})$ connected to gold wires, was placed on the top and bottom of the stack to distribute the current, and a dead load of $7 \mathrm{~kg}$ was put on top.

The stack was heated up to $800{ }^{\circ} \mathrm{C}$ in a vertical furnace before a current of $2 \mathrm{~A}$, corresponding to $0.5 \mathrm{~A} \mathrm{~cm}^{-2}$, was applied. The current was monitored throughout the measurement by recording the voltage drop across an external resistor. Ohmic behavior was confirmed by varying the current between $0.1 \mathrm{~A}$ and $2 \mathrm{~A}$ during a short portion of the measurement.

The aging program consisted of $2000 \mathrm{~h}$ at $800{ }^{\circ} \mathrm{C}$, followed by 30 thermal cycles between $800{ }^{\circ} \mathrm{C}$ and $100{ }^{\circ} \mathrm{C}$ and finally additional $2000 \mathrm{~h}$ at $800^{\circ} \mathrm{C}$. Temperature was monitored by two S-type thermocouples, one positioned close to the center of the stack and one positioned close to the bottom (see Fig. 1). The two thermocouples typically showed a difference of $10^{\circ} \mathrm{C}$ at $800{ }^{\circ} \mathrm{C}$. The area specific resistance was determined from the voltage drop between the Pt-wire connected to the steel and the Ptwire between the LSM plates (see Fig. 1) according to: 


$$
A S R=\frac{\Delta V_{\text {sample }}}{I} \cdot A_{\text {sample }}
$$

where $\Delta V_{\text {sample }}$ is the voltage drop, $I$ is the current and $A_{\text {sample }}$ is the nominal contact area $\left(4 \mathrm{~cm}^{2}\right)$ between the steel coupon and the LSM plate. Assuming negligible resistance across the steel, this set-up allows for measuring the ASR on each side of the sample independently $\left(\Delta \mathrm{V}_{1}\right.$ and $\Delta \mathrm{V}_{2}$ in Fig 1). The voltage drop across a single plate of LSM was also logged as a reference.

Microstructural characterization was performed using a scanning electron microscope (SEM, Zeiss Supra 35 Field Emission SEM) equipped with an energy dispersive X-ray (EDX)-detector (Noran System SIX X-ray microanalysis system). The steel coupons were cold vacuum embedded in epoxy, ground and polished in successive steps down to $1 \mu \mathrm{m}$ to reveal the cross section, and carbon coated. EDX data were collected at an acceleration voltage of $15 \mathrm{kV}$ and analyzed using the Noran System SIX software (Thermo Scientific, ver. 2.3). Quantification of the collected spectra was performed by standardless analysis and the results must therefore be considered semi-quantitative. To avoid errors due to overlapping peaks, quantification was based on the $\mathrm{K}$-lines for $\mathrm{Cr}, \mathrm{Mn}, \mathrm{Co}$ and $\mathrm{Fe}$, and the $\mathrm{L}$ lines for $\mathrm{Sr}$ and $\mathrm{La}$.

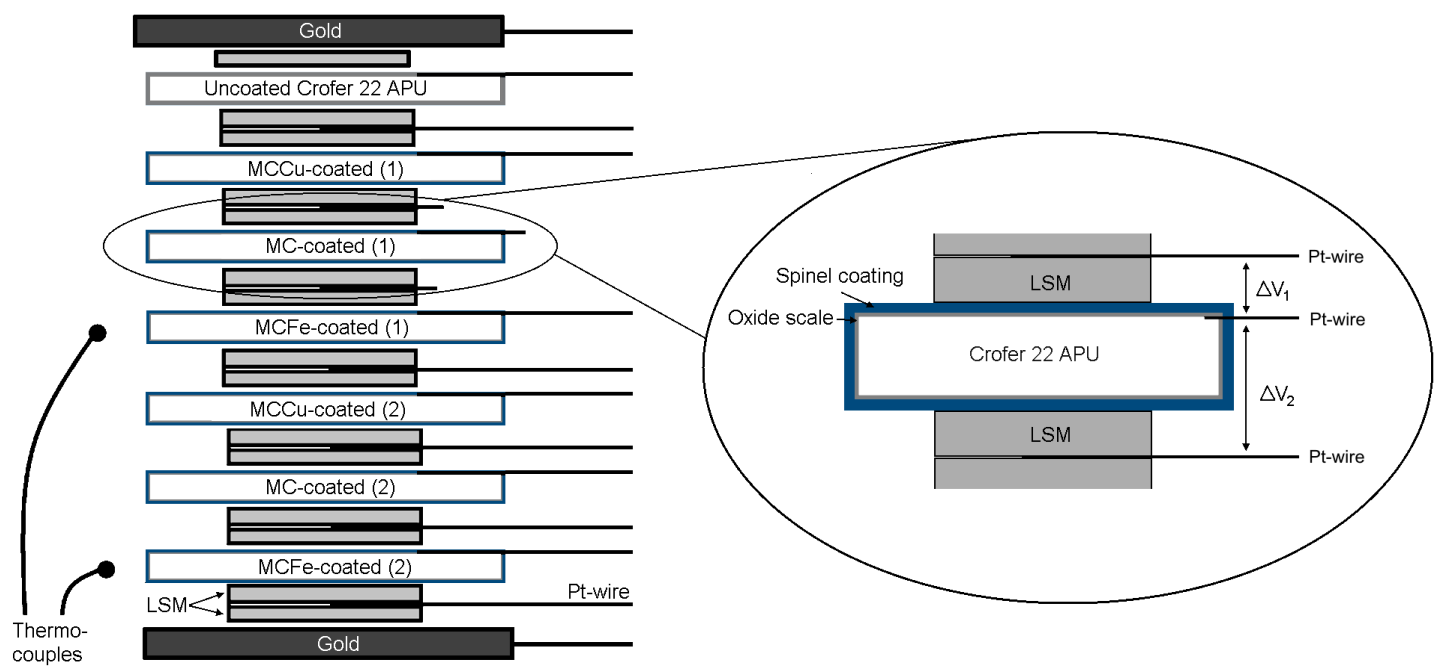

Figure 1. Illustration of set-up for measuring area specific resistance.

\section{Results and discussion}

\subsection{Characterization of as-prepared coatings}

Cross sectional SEM images and EDX analysis results of the coated samples after sintering ( $2 \mathrm{~h}$ at $900{ }^{\circ} \mathrm{C}$ in $\mathrm{N}_{2}-\mathrm{H}_{2}$ and $2 \mathrm{~h}$ at $800{ }^{\circ} \mathrm{C}$ in air) are shown in Figure 2. The coating thickness after sintering varies from sample to sample between 9 and $13 \mu \mathrm{m}$. The MC and MCFe coatings have densified similarly and have a porosity of 30-40 \% after sintering. The sintering heat treatment led to some oxidation of the alloy, evident by the ca. $0.6 \mu \mathrm{m}$ thermally grown oxide scale at the coating/alloy interface. According to EDX the oxide scale was mainly composed of $\mathrm{Cr}$ and $\mathrm{O}$ with minor amounts of $\mathrm{Mn}(<5 \mathrm{wt} . \%)$, indicating that the main component is $\mathrm{Cr}_{2} \mathrm{O}_{3}$. The compositions of the MC and MCFe coatings are close to the nominal powder compositions, i.e. $\mathrm{MnCo}_{2} \mathrm{O}_{4}$ and $\mathrm{MnCo}_{1.7} \mathrm{Fe}_{0.3} \mathrm{O}_{4}$. The $\mathrm{Co} / \mathrm{Mn}$ 
fraction is ca. $20 \%$ lower in both coatings, possibly due to Mn diffusion from the alloy. Both coatings contain trace amounts $(0.5 \mathrm{wt} . \%)$ of $\mathrm{Cr}$ and the $\mathrm{MC}$ coating contains trace amounts $(0.7 \mathrm{wt} . \%)$ of $\mathrm{Fe}$.

The MCCu coating can be divided into two parts, based on differences in density and composition. The first $2-3 \mu \mathrm{m}$ of the coating above the thermally grown oxide scale is highly dense, while the outer part has a density similar to the MC and MCFe coatings. The denser part is rich in Fe and lean in $\mathrm{Mn}$ and Co compared to the nominal powder composition, $\mathrm{MnCo}_{1.7} \mathrm{Cu}_{0.3} \mathrm{O}_{4}$. Significant amounts of $\mathrm{Fe}(15-$ $20 \mathrm{wt} . \%$ ) were also detected in the thermally grown oxide scale at the coating/alloy interface (see Figure S1 in the Supplementary material). The partial densification of the MCCu coating can be explained by $\mathrm{Fe}$ diffusion from the alloy into the coating leading to a volume expansion. Lower quantities of $\mathrm{Fe}$ (up to $5 \mathrm{wt} . \%$ ) have previously been observed in $(\mathrm{Mn}, \mathrm{Co})_{3} \mathrm{O}_{4}$ coatings after sintering and were attributed to rapid diffusion of $\mathrm{Fe}$ in the $\mathrm{Co}$ metal that forms when the coating is reduced during the first heat treatment step in $\mathrm{N}_{2}-\mathrm{H}_{2}[32,33]$. Here, $\mathrm{Cu}$ in the $\mathrm{MCCu}$ coating will also be reduced to its metallic state during heat treatment in $\mathrm{N}_{2}-\mathrm{H}_{2}$. The high diffusivity of $\mathrm{Fe}$ in $\mathrm{Cu}$ [34] allowed for larger amounts of Fe to diffuse from the alloy before a dense and continuous oxide scale was formed. Once the continuous oxide scale is formed, further diffusion of $\mathrm{Fe}$ is impeded.

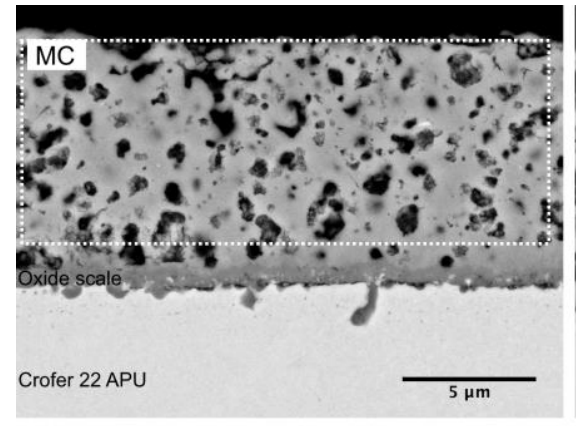

\begin{tabular}{lccccc} 
& $\mathrm{Mn}$ & $\mathrm{Co}$ & $\mathrm{O}$ & $\mathrm{Fe}$ & $\mathrm{Cr}$ \\
\hline [wt.\%] & 25.7 & 45.2 & 27.9 & 0.7 & 0.5 \\
Comp. & $\mathrm{Mn}_{1.12} \mathrm{Co}_{1.83} \mathrm{Fe}_{0.03} \mathrm{Cr}_{0.02} \mathrm{O}_{4}$ & \\
\hline
\end{tabular}

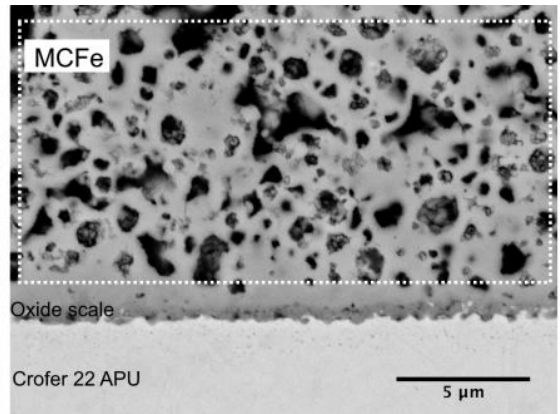

\begin{tabular}{lccccc} 
& $\mathrm{Mn}$ & $\mathrm{Co}$ & $\mathrm{O}$ & $\mathrm{Fe}$ & $\mathrm{Cr}$ \\
\hline [wt.\%] & 26.5 & 40.4 & 24.1 & 8.5 & 0.5 \\
Comp. & $\mathrm{Mn}_{1.09} \mathrm{Co}_{1.55} \mathrm{Fe}_{0.34} \mathrm{Cr}_{0.02} \mathrm{O}_{4}$ \\
\hline
\end{tabular}

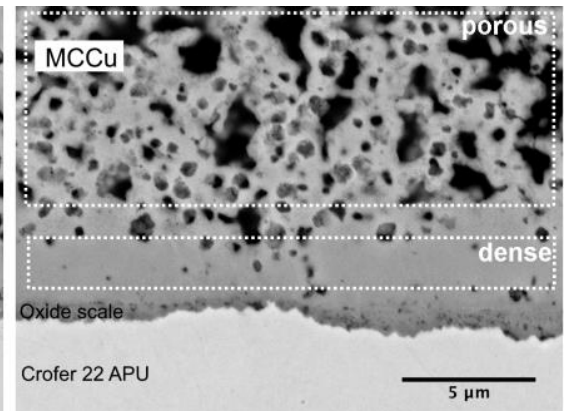

$\mathrm{Mn} \mathrm{Co} \mathrm{O} \quad \mathrm{Fe} \mathrm{Cu} \mathrm{Cr}$

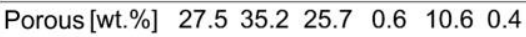
Comp. $\quad \mathrm{Mn}_{1.17} \mathrm{Co}_{1.41} \mathrm{Cu}_{0.38} \mathrm{Fe}_{0.03} \mathrm{Cr}_{0.02} \mathrm{O}_{4}$ Dense [wt.\%] $17.625 .326 .621 .6 \quad 6.3 \quad 2.6$ Comp. $\quad \mathrm{Mn}_{0.75} \mathrm{Co}_{1.01} \mathrm{Cu}_{0.23} \mathrm{Fe}_{0.9} \mathrm{Cr}_{0.12} \mathrm{O}_{4}$

Figure 2: SEM backscatter images of as-prepared spinel coatings on Crofer 22 APU and the composition in wt.\% according to EDX analysis. The stippled rectangles indicate analyzed area. The composition (comp.) is calculated based on cation fractions assuming the material is a stoichiometric spinel oxide.

\subsection{Oxidation kinetics}

Pre-oxidation of uncoated Crofer $22 \mathrm{APU}\left(2 \mathrm{~h}\right.$ at $900{ }^{\circ} \mathrm{C}$ in $\mathrm{N}_{2}-\mathrm{H}_{2}$ and $2 \mathrm{~h}$ at $800{ }^{\circ} \mathrm{C}$ in air) resulted in an average mass gain of $0.09 \pm 0.03 \mathrm{mg} \mathrm{cm}^{-2}$. Assuming all of the mass gain corresponds to oxygen uptake to form pure $\mathrm{Cr}_{2} \mathrm{O}_{3}$, the oxide scale thickness can be calculated from:

$$
t_{C r_{2} O_{3}}=\frac{(\Delta m / A) \cdot 3.167}{\rho\left(C r_{2} O_{3}\right)}
$$

where $\Delta m$ is the mass change [g], $A$ is the sample area $\left[\mathrm{cm}^{2}\right], \rho\left(\mathrm{Cr}_{2} \mathrm{O}_{3}\right)$ is the density of $\mathrm{Cr}_{2} \mathrm{O}_{3}$ $\left(5.21 \mathrm{~g} \mathrm{~cm}^{-3}\right.$ [35]) and 3.167 is the stoichiometric factor for converting the mass of oxygen to the equivalent mass of $\mathrm{Cr}_{2} \mathrm{O}_{3}$. As will be shown later, the thermally grown oxide scale on Crofer $22 \mathrm{APU}$ in reality consist of $\mathrm{Cr}_{2} \mathrm{O}_{3}$ and $(\mathrm{Mn}, \mathrm{Cr})_{3} \mathrm{O}_{4}$. However, due to the difficulty of determining the exact ratio between these two oxidation products and the exact $\mathrm{Mn} / \mathrm{Cr}$ ratio in $(\mathrm{Mn}, \mathrm{Cr})_{3} \mathrm{O}_{4}$, the oxide scale 
thickness is calculated assuming formation of $\mathrm{Cr}_{2} \mathrm{O}_{3}$ only. This assumption leads to an at maximum 25 $\%$ error for the calculated oxide scale thickness (based on the difference in calculated thickness assuming formation of pure $\mathrm{Cr}_{2} \mathrm{O}_{3}$ or pure $\mathrm{Mn}_{2} \mathrm{CrO}_{4}$ ).

According to Eq. 2 the mass gain of uncoated Crofer 22 APU during pre-oxidation corresponds to a $0.55 \mu \mathrm{m}$ thick $\mathrm{Cr}_{2} \mathrm{O}_{3}$ scale. This is close to the oxide scale thickness measured for the coated samples after the sintering heat treatment $\left(2 \mathrm{~h}\right.$ at $900{ }^{\circ} \mathrm{C}$ in $\mathrm{N}_{2}-\mathrm{H}_{2}$ and $2 \mathrm{~h}$ at $800{ }^{\circ} \mathrm{C}$ in air), where a pre-oxidation of the alloy also takes place (Fig. 2). Thus, the uncoated pre-oxidized alloy and the coated samples after sintering are equally "aged" before they are subjected to further oxidation.

The mass change of uncoated and spinel coated Crofer 22 APU measured during oxidation in air at $700{ }^{\circ} \mathrm{C}, 800{ }^{\circ} \mathrm{C}$ and $900{ }^{\circ} \mathrm{C}$ is shown in Figure 3. Note that the mass change during sintering of the coated samples and pre-oxidation of uncoated Crofer 22 APU is not included in these plots. The change in mass with time can be well described by parabolic kinetics, indicating scale growth controlled by solid state diffusion:

$$
(\Delta m / A)^{2}=k_{P} t+C
$$

where $k_{P}$ is the parabolic rate constant $\left[\mathrm{g}^{2} \mathrm{~cm}^{-4} \mathrm{~s}^{-1}\right], t$ is the time [s] and $C$ is an integration constant. The parabolic rate constants obtained by fitting the experimental data to Eq. 3 are listed in Table 2. The mass gain during the first $250 \mathrm{~h}$ of oxidation was ignored in this evaluation, to avoid contributions from transient oxidation kinetics [36]. The overall fit to the parabolic equation was good for all of the samples $\left(\mathrm{R}^{2}>0.99\right)$ with exception of bare Crofer 22 APU oxidized at $800{ }^{\circ} \mathrm{C}$, in which case the results were better fitted to two segments: one between $250-1000 \mathrm{~h}\left(\mathrm{k}_{\mathrm{P}}=1.8 \times 10^{-14} \mathrm{~g}^{2} \mathrm{~cm}^{-4} \mathrm{~s}^{-1}\right)$ and one between $1000-2000 \mathrm{~h}\left(\mathrm{k}_{\mathrm{P}}=2.9 \times 10^{-14} \mathrm{~g}^{2} \mathrm{~cm}^{-4} \mathrm{~s}^{-1}\right)$. The increase in oxidation rate after $1000 \mathrm{~h}$ correlated with observed local breakaway oxidation on the sample edges of the uncoated alloy (see Figure S2 in the Supplementary material).

Uncoated Crofer $22 \mathrm{APU}$ oxidized at $900{ }^{\circ} \mathrm{C}$ has a similar oxidation rate as reported by Huczkowski et al. [37] $\left(1 \times 10^{-12} \mathrm{~g}^{2} \mathrm{~cm}^{-4} \mathrm{~s}^{-1}\right)$. The oxidation rate of uncoated Crofer $22 \mathrm{APU}$ at $800{ }^{\circ} \mathrm{C}$ is however somewhat lower than we have previously reported for the same alloy batch $\left(4.2 \times 10^{-14} \mathrm{~g}^{2} \mathrm{~cm}^{-4} \mathrm{~s}^{-1}\right.$ [38] $)$ and what was measured by Gavrilov et al. [39] $\left(5.6 \times 10^{-14} \mathrm{~g}^{2} \mathrm{~cm}^{-4} \mathrm{~s}^{-1}\right)$ and Molin et al. [40] $\left(2.84 \times 10^{-14} \mathrm{~g}^{2}\right.$ $\left.\mathrm{cm}^{-4} \mathrm{~s}^{-1}\right)$. This can be attributed to the pre-oxidation heat treatment $\left(900{ }^{\circ} \mathrm{C}, \mathrm{N}_{2}-\mathrm{H}_{2}, 2 \mathrm{~h}\right.$ and $800{ }^{\circ} \mathrm{C}$, air, $2 \mathrm{~h}$ ). The alloy was pre-oxidized to allow for a closer comparison with the coated samples, which are oxidized during the sintering of the coatings.

The mass change results show that all three coating materials provide roughly the same degree of protection at $900{ }^{\circ} \mathrm{C}$. The parabolic oxidation rate constant is reduced by more than a factor of four compared to the uncoated alloy. The difference between coated and uncoated samples decreases with decreasing temperature and at $700{ }^{\circ} \mathrm{C}$ the mass gain of the coated samples is higher than or equal to the mass gain of uncoated Crofer 22 APU. This can in part be attributed to differences in Cr evaporation from the coated and uncoated samples. We have previously shown that a $\mathrm{MCFe}$ coating reduces the $\mathrm{Cr}$ evaporation rate of Crofer $22 \mathrm{APU}$ by a factor of $10-30$ at $800{ }^{\circ} \mathrm{C}$ in air with $3 \% \mathrm{H}_{2} \mathrm{O}$ [38]. Decreasing the temperature from $800{ }^{\circ} \mathrm{C}$ to $700{ }^{\circ} \mathrm{C}$ is here shown to decrease the oxidation rate by a factor of 10 , while the rate of $\mathrm{Cr}$ evaporation has been shown to decrease by only a factor of 2-3 in this temperature interval [41]. Thus, the relative influence of $\mathrm{Cr}$ evaporation on the mass change increases with decreasing temperature. Due to the lack of $\mathrm{Cr}$ evaporation data at the testing conditions in this study it is not possible to quantify the influence of $\mathrm{Cr}$ evaporation and conclude on whether the spinel coatings effectively reduce the oxidation rate $700{ }^{\circ} \mathrm{C}$. Extrapolating the measured mass gain of bare Crofer 22 APU at $700{ }^{\circ} \mathrm{C}$ forecasts a mass gain of $0.25 \mathrm{mg} \mathrm{cm}^{-2}$ after $40000 \mathrm{~h}$, which corresponds to only $1.5 \mu \mathrm{m}$ of $\mathrm{Cr}_{2} \mathrm{O}_{3}$ (Eq. 2). It may therefore be argued that the oxidation rate of Crofer $22 \mathrm{APU}$ at $700{ }^{\circ} \mathrm{C}$ is 
sufficiently low that further reduction by a protective coating is not needed. Nevertheless, to prevent $\mathrm{Cr}$ poisoning of the oxygen electrode a protective coating will still be necessary $[42,43]$.

At $700{ }^{\circ} \mathrm{C}$ and $800{ }^{\circ} \mathrm{C} \mathrm{MC}$ displays the lowest oxidation rate among the three coating materials, followed by $\mathrm{MCFe}$ and $\mathrm{MCCu}$. It is noteworthy that the $\mathrm{MCCu}$ coating results in the highest oxidation rate, considering this coating has a 2-3 $\mu \mathrm{m}$ thick inner layer of significantly higher density than the MC and MCFe coatings after sintering (Fig. 2). This shows that the dense $\mathrm{Mn}_{0.75} \mathrm{Co}_{1.01} \mathrm{Cu}_{0.23} \mathrm{Fe}_{0.9} \mathrm{Cr}_{0.12} \mathrm{O}_{4}$ layer is not effective in reducing oxygen inward diffusion or chromium outward diffusion.

The activation energy for oxidation was determined by fitting the parabolic rate constants to the Arrhenius equation:

$$
k_{P}=k_{0} \exp \left(-\frac{E_{A}}{R T}\right)
$$

where $E_{A}$ is the activation energy $\left[\mathrm{kJ} \mathrm{mol}^{-1}\right], R$ is the gas constant $\left[\mathrm{kJ} \mathrm{mol}{ }^{-1} \mathrm{~K}^{-1}\right], T$ is the temperature $[\mathrm{K}]$ and $k_{0}$ is a constant. The plots of $\mathrm{k}_{\mathrm{P}}$ as function of temperature are shown in Figure $3 \mathrm{~d}$ and the deduced activation energies are listed in Table 2. The parabolic rate constants for the spinel coated samples display good linearity in the Arrhenius plot in the investigated temperature range and the activation energies fall within the same range $\left(258-289 \mathrm{~kJ} \mathrm{~mol}^{-1}\right)$. These values are similar to the activation energies previously reported for the oxidation of several uncoated FSS in the same temperature range $[41,44-46]$. In these studies, the activation energy was compared to the activation energy for cation self-diffusion in $\mathrm{Cr}_{2} \mathrm{O}_{3}\left(255 \mathrm{~kJ} \mathrm{~mol}^{-1}\right.$ [47]) to suggest that the oxidation rate is determined by outward diffusion of $\mathrm{Cr}$ through the oxide scale. The similar activation energy for the spinel-coated samples may suggest the same mechanism is valid, however, the activation energy could also result from a combination of several mechanism. Horita et al. [48] showed that oxygen diffusion through $\mathrm{MnCo}_{2} \mathrm{O}_{4}$ coated FSS was slowest through a reaction layer formed at the interface between the coating and thermally grown oxide scale, suggesting that the growth rate of the oxide scale on the alloy may be limited by this reaction layer. A similar reaction layer was observed to form at the oxide scale/coating interface in this study, as will be presented in Section 3.4.

The temperature variation of the parabolic rate constants for uncoated Crofer 22 APU deviates from linearity in the Arrhenius plot and the apparent activation energy is significantly higher $\left(370 \mathrm{~kJ} \mathrm{~mol}^{-1}\right)$ than previously reported by Palcut et al. $\left(252 \mathrm{~kJ} \mathrm{~mol}^{-1}\right)$ for the same alloy between $800{ }^{\circ} \mathrm{C}$ and $900{ }^{\circ} \mathrm{C}$ [44]. The difference could be due to the pre-oxidation treatment in the current study. However, Skilbred et al. [45] also reported a higher activation energy for oxidation of Sandvik HT between 700 and 1000 ${ }^{\circ} \mathrm{C}\left(396 \pm 33 \mathrm{~kJ} \mathrm{~mol}^{-1}\right)$ than between 800 and $900{ }^{\circ} \mathrm{C}\left(272 \pm 20 \mathrm{~kJ} \mathrm{~mol}^{-1}\right)$. It is thus possible that the prevalent oxidation mechanism changes in the investigated temperature interval.

Table 2. Parabolic oxidation rate constants $\left(\mathrm{k}_{\mathrm{p}}\right)$ and activation energy $\left(\mathrm{E}_{\mathrm{A}}\right)$ of oxidation of pre-oxidized and spinel coated Crofer 22 APU oxidized in air

\begin{tabular}{lcccc}
\hline Sample & \multicolumn{3}{c}{$\mathrm{k}_{\mathrm{p}}\left[\mathrm{g}^{2} \mathrm{~cm}^{-4} \mathrm{~s}^{-1}\right]$} & $\mathrm{E}_{\mathrm{A}}\left[\mathrm{kJ} \mathrm{mol}^{-1}\right]$ \\
\hline & $700{ }^{\circ} \mathrm{C}$ & $800^{\circ} \mathrm{C}$ & $900^{\circ} \mathrm{C}$ & \\
\cline { 2 - 4 } MC coated & $5.5 \times 10^{-16}$ & $0.9 \times 10^{-14}$ & $2.5 \times 10^{-13}$ & 289 \\
MCFe coated & $6.9 \times 10^{-16}$ & $1.3 \times 10^{-14}$ & $2.6 \times 10^{-13}$ & 281 \\
MCCu coated & $11 \times 10^{-16}$ & $1.6 \times 10^{-14}$ & $2.5 \times 10^{-13}$ & 258 \\
Pre-oxidized Crofer 22 APU & $4.3 \times 10^{-16}$ & $1.8 \times 10^{-14} *$ & $11 \times 10^{-13}$ & 370 \\
\hline
\end{tabular}

* Evaluated between 250 and $1000 \mathrm{~h}$ of oxidation. 
a)

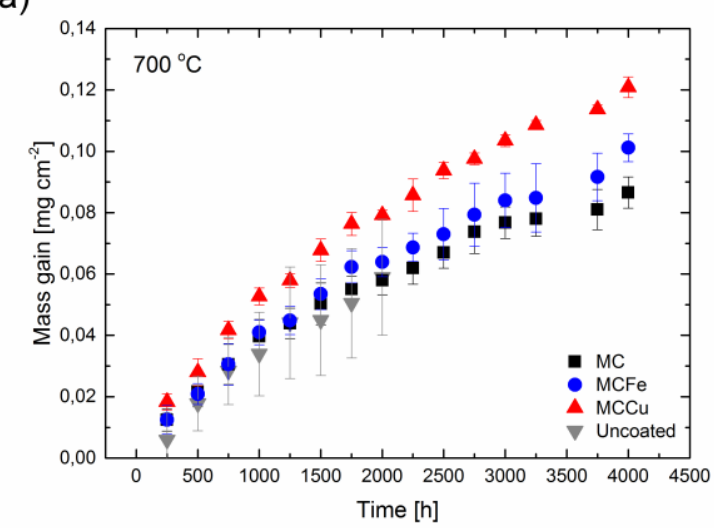

c)

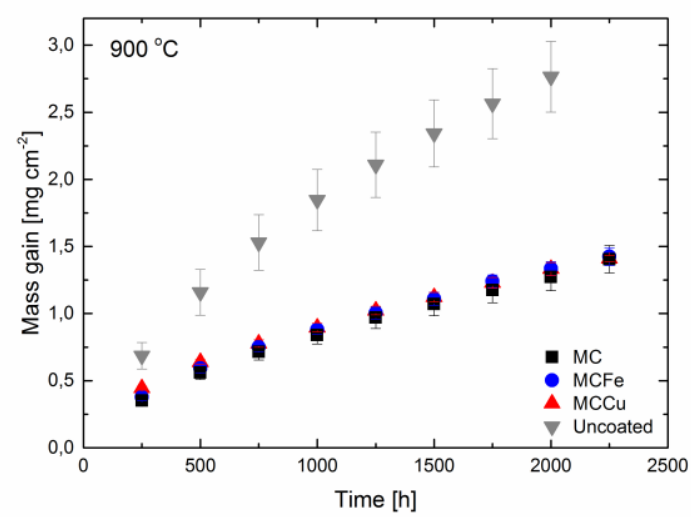

b)

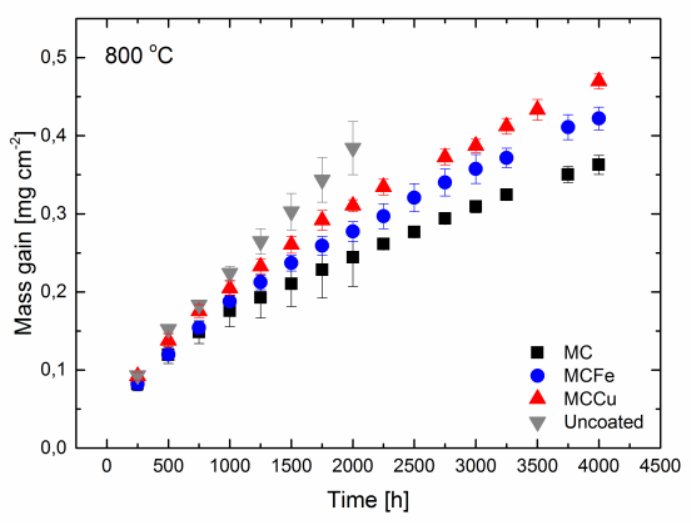

d)

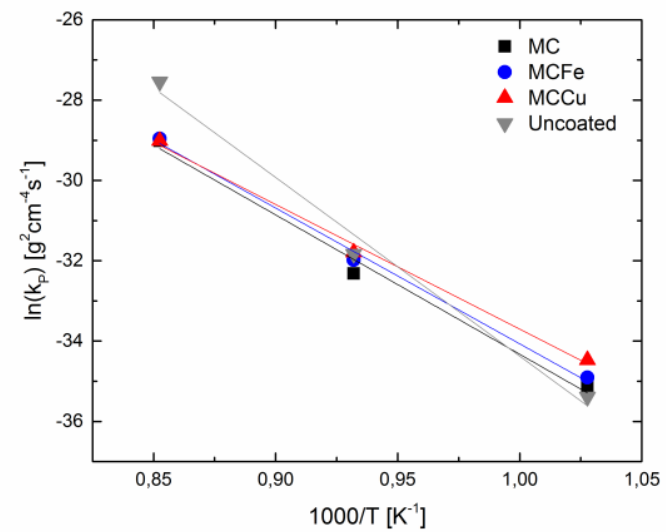

Figure 3: a-c) Mass gain of uncoated pre-oxidized and spinel coated Crofer 22 APU during discontinuous oxidation in air at (a) $700{ }^{\circ} \mathrm{C}$, (b) $800{ }^{\circ} \mathrm{C}$, and (c) $900{ }^{\circ} \mathrm{C}$. Each point is the average of 3-5 samples and the error bars show the standard deviation. (d) Arrhenius plot of parabolic rate constant $\left(\mathrm{k}_{\mathrm{P}}\right)$.

\subsection{Area specific resistance}

The area specific resistance (ASR) across the scale and coating was measured at $800{ }^{\circ} \mathrm{C}$ under a current load of $0.5 \mathrm{~A} \mathrm{~cm}^{-2}$. Figure 4 shows the development with time of selected, representative samples after totally $3400 \mathrm{~h}$ at $800^{\circ} \mathrm{C}$, including 30 thermal cycles between $100^{\circ} \mathrm{C}$ and $800^{\circ} \mathrm{C}$. Each measurement is for one side of the sample (see Fig. 1). There was no systematic difference between the two sides of the samples, i.e. there was no indication that the current direction across the sample influenced the ASR, unlike what has been reported in some studies [49,50].

At the end of the aging test $\left(4370 \mathrm{~h}\right.$ at $\left.800^{\circ} \mathrm{C}\right)$, the ASR is $14 \pm 1 \mathrm{~m} \Omega \mathrm{cm}^{2}$ for the MC coated, $16 \pm 2 \mathrm{~m} \Omega \mathrm{cm}^{2}$ for the MCFe coated, $15 \pm 1 \mathrm{~m} \Omega \mathrm{cm}^{2}$ for the $\mathrm{MCCu}$ coated, and $50 \mathrm{~m} \Omega \mathrm{cm}^{2}$ for the uncoated Crofer 22 APU (average and standard deviation of four individual measurements for the coated samples). These values are in the same range as previously reported for $\mathrm{Mn}_{1.5} \mathrm{Co}_{1.5} \mathrm{O}_{4}$ coated Crofer 22 APU $[8,31]$ and AISI441 [51] in contact with LSM.

The ASR measured here is a function of the thickness and conductivity of the thermally grown oxide scale, the coating, the LSM plate, and any additional reaction products formed at these interfaces. A dual layer of $\mathrm{LSM}$ and $\mathrm{Co}_{3} \mathrm{O}_{4}$ has previously been suggested as a possible coating material for SOFC interconnects, shown to reduce the parabolic oxidation rate of Crofer 22 APU by more than a factor of 6 at $850{ }^{\circ} \mathrm{C}$ [52]. Thus, the LSM-Co $\mathrm{O}_{4}$ contact layer used here for the ASR measurement likely aided in 
limiting the ASR of uncoated Crofer 22 APU. Nevertheless, the ASR of uncoated Crofer 22 APU is three times greater than the ASR of the spinel coated samples.

The electrical conductivity of the spinel coating materials $\left(47-142 \mathrm{~S} \mathrm{~cm}^{-1}\right.$ at $800{ }^{\circ} \mathrm{C} \mathrm{[15])} \mathrm{is} \mathrm{at} \mathrm{least}$ 100 times larger than the electrical conductivity typically reported for $\mathrm{Cr}_{2} \mathrm{O}_{3}$ and $(\mathrm{Mn}, \mathrm{Cr})_{3} \mathrm{O}_{4}[12,22]$, which constitute the thermally grown oxide scale. For a $20 \mu \mathrm{m}$ thick dense coating, a change in the electrical conductivity from 47 to $142 \mathrm{~S} \mathrm{~cm}^{-1}$ would only change the ASR by $0.03 \mathrm{~m} \Omega \mathrm{cm}^{2}$.

Consequently, the thickness and conductivity of the coating itself has negligible influence on the ASR. It affects the ASR only via its effect on the growth of the alloy's oxide scale. Indeed, a similar ASR is measured for the MCFe and $\mathrm{MCCu}$ coated samples despite MCFe having a three times lower electrical conductivity than $\mathrm{MCCu}$. Assuming the specific conductivity of the thermally grown oxide scale does not change with time, the ASR should increase parabolically with time, reflecting the parabolic growth rate of the oxide scale. Here, the increase in ASR with time is sub-parabolic (Fig. 4). This could be due to changes in the specific electrical conductivity of the oxide scale with time. It is known that the electrical conductivity of $\mathrm{Cr}_{2} \mathrm{O}_{3}$ may change by orders of magnitude depending on amount and type of impurities present $[22,23]$. However, a contributing factor to the sub-parabolic behavior is that the ASR across LSM decreases with time throughout the whole measurement. This can be attributed to densification of the $\mathrm{Co}_{3} \mathrm{O}_{4} / \mathrm{LSM}$ contact layer on the LSM plates, which were not sintered after spray coating and the mild sintering conditions of the LSM plates themselves. Furthermore, creep/sintering effects leading to an improvement of the contact area between the LSM plates and the samples will result in an ASR decrease [53]. Although changes in the oxide scale and the coating are somewhat masked by changes related to the LSM contact plates, this type of ASR measurement is a valuable compliment to measurements utilizing Pt or Ag contacts, as the contact resistance between the interconnect and cathode current collector in a real SOFC stack is better imitated.

From the increase in ASR with time the degradation rate can be expressed as $\Delta \mathrm{ASR} / 1000 \mathrm{~h}$. The degradation rates were calculated based on a linear fit of the measurement between 3870 and $4370 \mathrm{~h}$ and are given in Figure 4. Bare Crofer 22 APU has a 3-6 times higher degradation rate than the coated samples. The degradation rates of the coated samples follow the trends of the oxidation rate constants (cf. Fig. 3b), i.e. MC coated samples have the lowest ASR degradation rate followed by the MCFe and the MCCu coated samples.

The acceptable limit for the interconnect ASR depends on the specific application of the stack and the quality of the cells. The stack ASR should generally not be dominated by the interconnect and hence staying below $20 \%$ of the total stack ASR would be a reasonable engineering target. In some publications $50 \mathrm{~m} \Omega \mathrm{cm}^{2}$ is suggested as an upper limit [4]. This limit is reached by uncoated Crofer 22 APU already after $4370 \mathrm{~h}$ at $800{ }^{\circ} \mathrm{C}$ when contacted to LSM. By making an extrapolation of the linear degradation rates, the ASR after $40000 \mathrm{~h}$ at $800{ }^{\circ} \mathrm{C}$ is predicted to reach $35 \pm 12 \mathrm{~m} \Omega \mathrm{cm}^{2}$ for MC coated, $48 \pm 24 \mathrm{~m} \Omega \mathrm{cm}^{2}$ for MCFe coated, $51 \pm 23 \mathrm{~m} \Omega \mathrm{cm}^{2}$ for MCCu coated, and $178 \mathrm{~m} \Omega \mathrm{cm}^{2}$ for uncoated Crofer 22 APU. Thus, all the coated samples meet the requirement of an interconnect ASR below $50 \mathrm{~m} \Omega \mathrm{cm}^{2}$.

As discussed above, the ASR of the LSM plate decreases with time, giving a negative degradation rate. If the ASR change measured for the LSM plate is subtracted from the ASR measured for the steel samples the degradation rate of the coated samples nearly doubles. An extrapolation of the degradation rate now predicts the ASR after $40000 \mathrm{~h}$ at $800{ }^{\circ} \mathrm{C}$ to reach $75 \pm 12 \mathrm{~m} \Omega \mathrm{cm}^{2}$ for MC coated, $87 \pm 24 \mathrm{~m} \Omega \mathrm{cm}^{2}$ for MCFe coated, $90 \pm 23 \mathrm{~m} \Omega \mathrm{cm}^{2}$ for MCCu coated, and $217 \mathrm{~m} \Omega \mathrm{cm}^{2}$ for uncoated Crofer 22 APU. The linear extrapolation of the ASR as well as subtracting the contribution from the LSM plate may be viewed as the "worst-case-scenario" since the oxidation kinetics point to a parabolic development of oxide scale thickness with time.

The temperature dependence of the ASR was determined by a step-wise cooling from $800{ }^{\circ} \mathrm{C}$ to $300{ }^{\circ} \mathrm{C}$ at the end of the measurement and is shown in Figure 4c. Each temperature step was held for 
$10 \mathrm{~h}$ to allow for equilibration, however, the change in ASR during this period of time was negligible. The activation energies were determined from the slope of the curves according to:

$$
\frac{A S R}{T}=A \cdot \exp \left(\frac{E_{a}}{k T}\right)
$$

where $A$ is a pre-exponential factor $\left[\Omega \mathrm{cm}^{-2} \mathrm{~K}^{-1}\right], E_{a}$ is the activation energy $\left[\mathrm{kJ} \mathrm{mol}{ }^{-1}\right], k$ is Boltzmann's constant $\left[\mathrm{eV} \mathrm{K}^{-1}\right]$ and $T$ is the temperature $[\mathrm{K}]$. The temperature dependence of spinel coated and bare Crofer 22 APU is Arrhenius like over the whole temperature range and the activation energies for the coated samples $\left(77-78 \mathrm{~kJ} \mathrm{~mol}^{-1}\right)$ are slightly larger than the activation energy for bare Crofer $22 \mathrm{APU}$ $\left(65 \mathrm{~kJ} \mathrm{~mol}^{-1}\right)$. These activation energy values are comparable to those previously reported by Kruk et al. for $\mathrm{Mn}_{1.5} \mathrm{Co}_{1.5} \mathrm{O}_{4}$ coated AL453 in contact with $\mathrm{La}_{0.8} \mathrm{Sr}_{0.2} \mathrm{Co}_{0.5} \mathrm{Mn}_{0.5} \mathrm{O}_{3}\left(65-68 \mathrm{~kJ} \mathrm{~mol}^{-1}\right)$ [54]. The larger activation energy for the coated samples may indicate that different parts of the coating/oxide scale interface dominate the resistance or that the specific electrical conductivity of the oxide scale is influenced by doping by the elements in the coating material. The temperature dependence of the LSM reference plate is Arrhenius like in the range from $300-700^{\circ} \mathrm{C}$ and the activation energy is lower $\left(39 \mathrm{~kJ} \mathrm{~mol}^{-1}\right)$.

a)

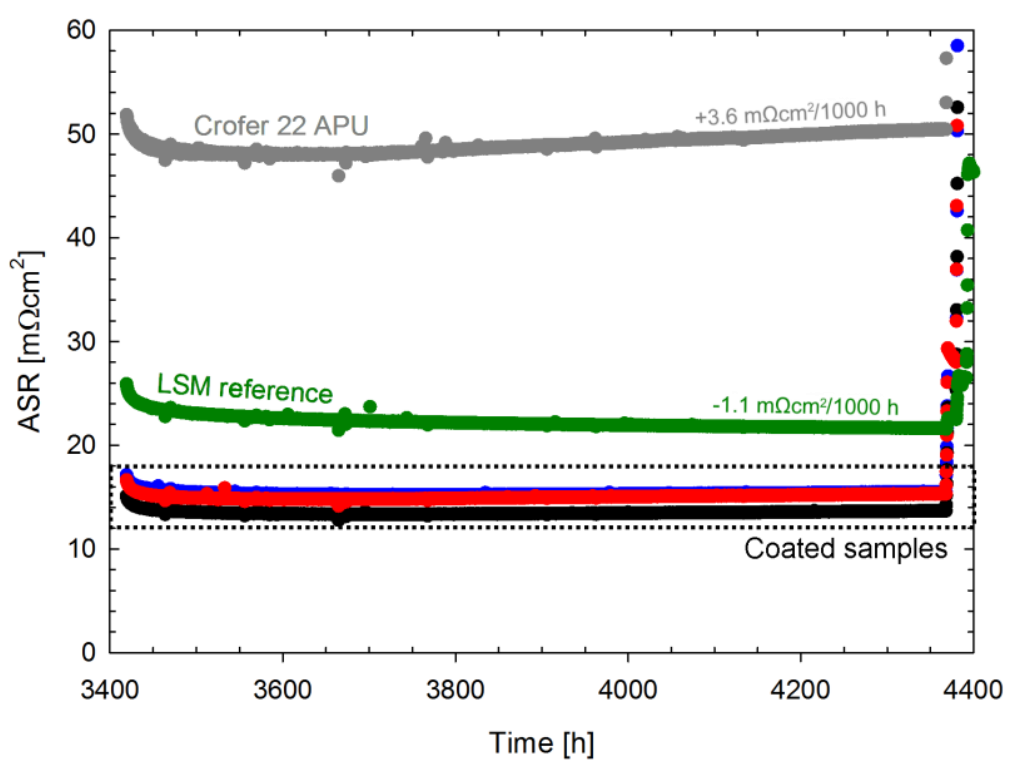

b)
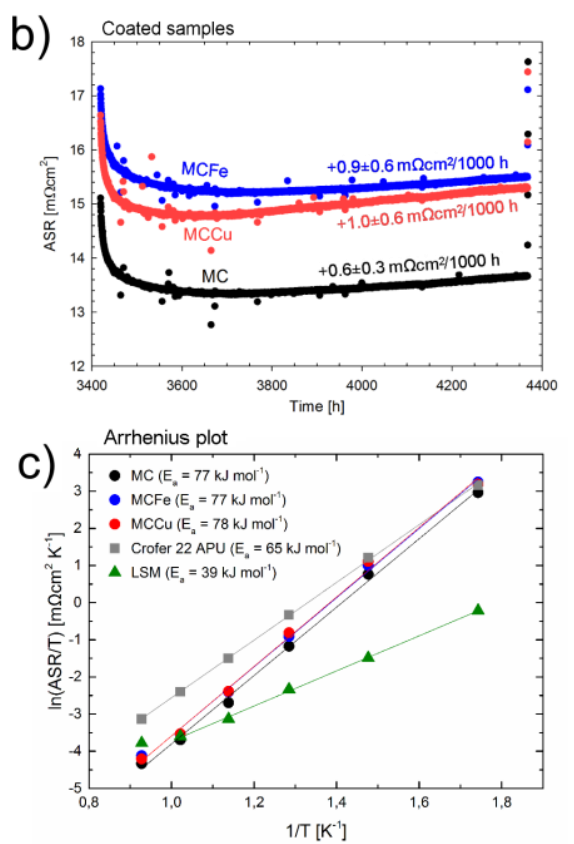

Figure 4: Area specific resistance of spinel coated and bare Crofer 22 APU measured in air at $800{ }^{\circ} \mathrm{C}$ using LSM as contacting plates and a current density of $0.5 \mathrm{~A} \mathrm{~cm}^{-2}$. b) Excerpt of a), scaled to better display the difference between the spinel-coated samples. c) Area specific resistance as a function of temperature determined by step-wise cooling.

\subsection{Microstructural characterization after oxidation and ASR testing}

\subsubsection{Samples oxidized at $700{ }^{\circ} \mathrm{C}$}

Figure 5 shows a backscatter electron (BSE) SEM image and EDX linescan of MC coated Crofer 22 APU after $4000 \mathrm{~h}$ oxidation in air at $700{ }^{\circ} \mathrm{C}$. There are minimal changes to the thermally grown oxide scale and the coating compared to the as-prepared state (cf. Fig. 2). The thickness of the thermally grown oxide scale varies between 0.5 and $1 \mu \mathrm{m}$ along the interface. These observations are in line with 
the mass change measurements, showing only $0.09 \mathrm{mg} \mathrm{cm}^{-2}$ mass gain after $4000 \mathrm{~h}$ at $700{ }^{\circ} \mathrm{C}$, corresponding to growth of $0.55 \mu \mathrm{m} \mathrm{Cr}_{2} \mathrm{O}_{3}$. The EDX linescan reveals a narrow $(<1 \mu \mathrm{m})$ inter-diffusion zone between the coating and thermally grown oxide scale consisting of $\mathrm{Mn}, \mathrm{Co}, \mathrm{Cr}, \mathrm{Fe}$ and $\mathrm{O}$. Due to the narrow width of this inter-diffusion zone relative to the EDX interaction volume it was difficult to determine its exact composition and measure the average thickness.
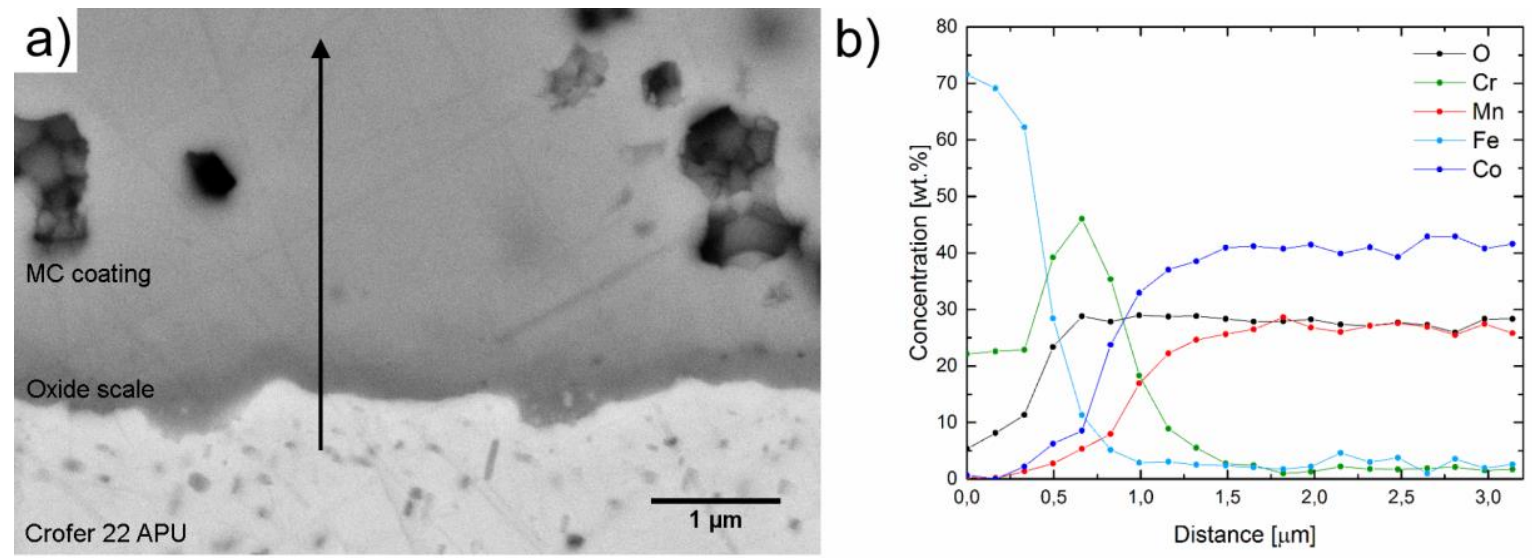

Figure 5: MC coated Crofer 22 APU oxidized $4000 \mathrm{~h}$ in air at $700{ }^{\circ} \mathrm{C}$. a) SEM-BSE, b) EDX linescan along line indicated in a).

\subsubsection{Samples oxidized at $800^{\circ} \mathrm{C}$}

Figure 6a shows a SEM image and EDX maps of bare Crofer 22 APU after the ASR measurement $\left(4370 \mathrm{~h}\right.$ in air at $\left.800^{\circ} \mathrm{C}\right)$. The thermally grown oxide scale consists of an inner $\mathrm{Cr}$-rich layer $\left(\mathrm{Cr}_{2} \mathrm{O}_{3}\right)$ and an outer layer comprising both $\mathrm{Cr}$ and $\mathrm{Mn}\left((\mathrm{Mn}, \mathrm{Cr})_{3} \mathrm{O}_{4}\right)$. The average thickness of the whole oxide scale was measured to $3.0 \pm 1.1 \mu \mathrm{m}$. Internal oxidation of $\mathrm{Ti}$ is observed in the subscale region as dark spots in the brighter contrast alloy. The $\mathrm{LSM}-\mathrm{Co}_{3} \mathrm{O}_{4}$ contact layer is well adherent and appears to have reacted with the thermally grown oxide scale. As discussed in Section 3.3, the contact layer has likely aided in limiting the ASR of the uncoated Crofer 22 APU. However, the contact layer does not act as an adequate barrier against $\mathrm{Cr}$ diffusion/evaporation. On average $10 \mathrm{wt} . \% \mathrm{of} \mathrm{Cr}$ is measured in the first $20 \mu \mathrm{m}$ of the $\mathrm{LSM}-\mathrm{Co}_{3} \mathrm{O}_{4}$ contact layer closest to the oxide scale.

Figure $6 \mathrm{~b}$ shows a SEM image and EDX maps for one of the MC coated Crofer 22 APU samples after ASR measurement. There is no systematic difference between the oxide scale and coating on the two sides of the sample, i.e. there is no apparent influence of the current direction across the sample. The average thickness of the thermally grown oxide scale is $0.6 \pm 0.4 \mu \mathrm{m}$, which is effectively the same as the oxide scale thickness observed on the as-prepared sample (Fig. 2). There is no measureable change in composition of the thermally grown oxide scale compared to the as-prepared sample. I.e. the scale consists of mainly $\mathrm{Cr}_{2} \mathrm{O}_{3}$, with minor amounts of $\mathrm{Mn}(<5 \mathrm{wt} . \%)$.

The MC coating can be divided into two main parts, based on differences in both morphology and composition. Closest to the thermally grown oxide scale the coating is highly dense, while further away the coating porosity is similar to the state after sintering (Fig. 2). The densified part of the coating contains on average $25 \mathrm{wt} . \%$ of Cr, $27 \mathrm{wt} . \%$ of Co, 17 wt.\% of Mn, 1 wt. $\%$ of Fe and 30 wt. $\%$ of O according to EDX analysis. The $\mathrm{Cr}$ concentration in the densified part of the coating decreased linearly from the interface with the thermally grown oxide scale to the interface between the dense and porous parts of the MC coating. Only trace amounts of $\mathrm{Cr}(<1 \mathrm{wt} . \%)$ are detected in the porous part of the coating. The parts of the coating containing more than $5 \mathrm{wt} . \% \mathrm{Cr}$ will from hereon be designated as the "reaction layer". The Co content is nearly constant throughout the whole coating while the Mn content increases from the oxide scale/coating interface into the porous part of the coating. The outermost $1 \mu \mathrm{m}$ 
of the coating at the interface with the LSM- $\mathrm{Co}_{3} \mathrm{O}_{4}$ contact layer are Mn-depleted, possibly due to $\mathrm{Mn}$ diffusion into $\mathrm{LSM}-\mathrm{Co}_{3} \mathrm{O}_{4}$. No $\mathrm{Cr}$ could be detected in the contact layer by EDX analysis, thus the spinel coating served as an effective barrier against $\mathrm{Cr}$ diffusion/evaporation. The protective action can be attributed to the formation of the $\mathrm{Cr}$-rich $(\mathrm{Mn}, \mathrm{Co}, \mathrm{Cr}, \mathrm{Fe})_{3} \mathrm{O}_{4}$ reaction layer at the oxide scale/coating interface, which effectively retards outward diffusing $\mathrm{Cr}$ from the alloy. Partial densification of the $\mathrm{MC}$ coating can be also be attributed to the incorporation of $\mathrm{Cr}$ resulting in a volume expansion.

The composition and morphology of the MCFe and MCCu coated samples follow the same trends as described above for the MC coated sample (Figures S3 and S4 in the Supplementary material).i.e. the coatings can be divided into a dense Cr-rich part (reaction layer) and a porous part containing less than 1 wt.\% of $\mathrm{Cr}$. The concentrations of $\mathrm{Fe}$ and $\mathrm{Cu}$ in the $\mathrm{MCFe}$ and $\mathrm{MCCu}$ coatings, respectively, are constant in the porous parts of the coatings and decrease towards the oxide scale/coating interface. Thus, the reaction layer is primarily composed of $(\mathrm{Mn}, \mathrm{Co}, \mathrm{Cr})_{3} \mathrm{O}_{4}$, with minor amounts of $\mathrm{Fe}$ and $\mathrm{Cu}$. The whole $\mathrm{MCCu}$ coating (dense and porous parts) contains on average $2 \mathrm{wt} . \% \mathrm{Fe}$ after the ASR measurement, indicating Fe-diffusion into the $\mathrm{LSM} / \mathrm{Co}_{3} \mathrm{O}_{4}$ contact layer. Also for the $\mathrm{MCFe}$ and $\mathrm{MCCu}$ coated samples there is no detectable $\mathrm{Cr}$ in the $\mathrm{LSM}-\mathrm{Co}_{3} \mathrm{O}_{4}$ contact layer, i.e. these coatings work well as Cr-barriers.

The average thickness of the $\mathrm{Cr}$-rich $(\mathrm{Mn}, \mathrm{Co}, \mathrm{Cr})_{3} \mathrm{O}_{4}$ reaction layer was measured to $3.6 \pm 1.0 \mu \mathrm{m}$ on the MC coated sample, $3.4 \pm 0.6 \mu \mathrm{m}$ on the MCFe coated sample and $4.2 \pm 0.7 \mu \mathrm{m}$ on the MCCu coated sample. Thus, there is no significant difference in reaction layer thickness between $\mathrm{MC}$ and MCFe coatings. Considering a dense Cr-containing layer formed on the MCCu coating after sintering (Fig. 2c) there appears to be minor differences in the growth rate of the reaction layers on the three coatings.

The microstructural features of the ASR tested samples and those oxidized freely hanging in air at $800{ }^{\circ} \mathrm{C}$ were similar. The thickness of the thermally grown oxide scale remained nearly unchanged from the as-prepared state to more than $4000 \mathrm{~h}$ of oxidation at $800^{\circ} \mathrm{C}$, despite the fact that a significant mass gain was measured during oxidation. For example, the thermally grown oxide scale on the $\mathrm{MC}$ coated sample measured ca. $0.6 \mu \mathrm{m}$ after $4000 \mathrm{~h}$ at $800{ }^{\circ} \mathrm{C}$, while the mass gain $\left(0.36 \mathrm{mg} \mathrm{cm}^{-2}\right)$ corresponds to growth of a $2.2 \mu \mathrm{m}$ thick $\mathrm{Cr}_{2} \mathrm{O}_{3}$ scale according to Eq. 2. On the other hand, the Cr-rich $(\mathrm{Mn}, \mathrm{Co}, \mathrm{Cr})_{3} \mathrm{O}_{4}$ reaction layer grew with time. For the $\mathrm{MC}$ coated sample oxidized at $800{ }^{\circ} \mathrm{C}$ the reaction layer increased from $2.1 \pm 0.6 \mu \mathrm{m}$ after $2000 \mathrm{~h}$ to $3.5 \pm 0.8 \mu \mathrm{m}$ after $4000 \mathrm{~h}$ of oxidation. i.e. $\mathrm{Cr}$ from the alloy is oxidized to form a $\mathrm{Cr}_{2} \mathrm{O}_{3}$ scale, and $\mathrm{Cr}$ from this scale reacts at the same rate with the coating to form a Cr-rich reaction layer between the coating and the $\mathrm{Cr}_{2} \mathrm{O}_{3}$ scale. 


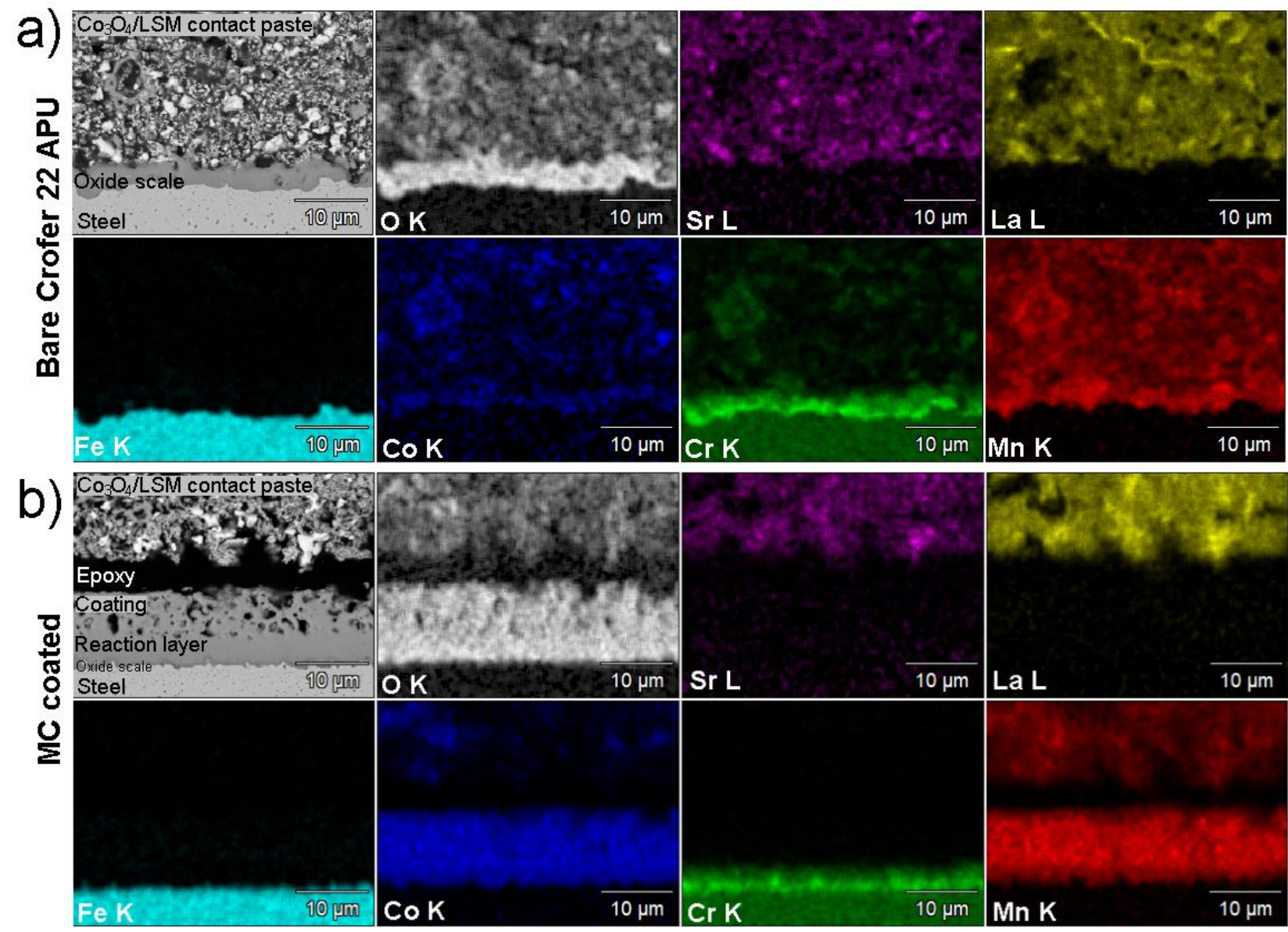

Figure 6: SEM image and EDX maps after area specific resistance measurement at $800{ }^{\circ} \mathrm{C}$ for $4370 \mathrm{~h}$. a) bare Crofer 22 APU, b) MC coated Crofer 22 APU.

\subsubsection{Samples oxidized at $900{ }^{\circ} \mathrm{C}$}

Figure 7a shows a cross sectional SEM image of bare Crofer 22 APU after $2000 \mathrm{~h}$ oxidation at $900{ }^{\circ} \mathrm{C}$. The thermally grown oxide scale consists of two distinct layers, distinguishable by a contrasts difference in the BSE SEM image. Pores are observed at the interface between these two layers. The outer layer has composition close to $\mathrm{MnCr}_{2} \mathrm{O}_{4}$ according to EDX analysis and varies in thickness between 2-4 $\mu \mathrm{m}$. The inner layer is $10-13 \mu \mathrm{m}$ thick and consists of $\mathrm{Cr}_{2} \mathrm{O}_{3}$, except for in few distinct areas closest to the interface with the alloy, which contain Mn. The Mn-enriched areas are emphasized in Figure $7 \mathrm{a}$ and are distinguishable in the BSE SEM image by their slightly higher brightness relative to $\mathrm{Cr}_{2} \mathrm{O}_{3}$. The average thickness of the whole oxide scale was determined to be $15 \pm 2 \mu \mathrm{m}$ based on measurement of several representative SEM images. The calculated $\mathrm{Cr}_{2} \mathrm{O}_{3}$ thickness based on the mass gain measurement is $17 \mu \mathrm{m}$ according to Eq. 2 . The calculated and measured oxide scale thickness are in good agreement considering that the oxide scale consist of not only $\mathrm{Cr}_{2} \mathrm{O}_{3}$ and that some of the mass gain is due to internal oxidation.

Representative SEM images of the spinel-coated samples after oxidation at $900{ }^{\circ} \mathrm{C}$ for $2000 \mathrm{~h}$ are shown in Figures $7 \mathrm{~b}-\mathrm{d}$. The density of the coating has increased compared to the "as-prepared" state (cf. Fig. 2). The thermally grown oxide scale on the coated samples consists of $\mathrm{Cr}_{2} \mathrm{O}_{3}$ with Mn-enrichment in areas close to the interface with the alloy. The ratio of the Mn-enriched areas relative to pure $\mathrm{Cr}_{2} \mathrm{O}_{3}$ is greater than observed for uncoated Crofer $22 \mathrm{APU}$, particularly on the MCFe and MCCu coated samples. The oxide scale on the MC coated sample $(2.8 \pm 0.9 \mu \mathrm{m})$ is slightly thinner than on the MCFe $(3.9 \pm 1.0 \mu \mathrm{m})$ and $\mathrm{MCCu}(4.5 \pm 1.4 \mu \mathrm{m})$ coated samples. The variation in oxide scale thickness along the 
samples was large, as reflected by the large standard deviations. Nevertheless, the difference in oxide scale thickness between the three coated samples is significantly greater than indicated by the mass change measurements (Fig. 3c). In all three cases, the measured oxide scale thickness is smaller than the thickness calculated from the mass gain assuming formation of pure $\mathrm{Cr}_{2} \mathrm{O}_{3}$. An overview of the calculated and measured oxide scale thicknesses on the spinel coated samples is given in Table 3 .

Figure 8 shows an EDX linescan of the MC coated sample along the line indicated in Figure $7 \mathrm{~b}$. The 1-2 $\mu \mathrm{m}$ of the coating closest to the thermally grown oxide scale contain $30-35 \mathrm{wt} . \% \mathrm{Cr}$ and the stoichiometry according to EDX is close to $\mathrm{Mn}_{0.5} \mathrm{CoCr}_{1.5} \mathrm{O}_{4}$. The Cr-content decreases gradually outwards into the coating, reaching below $1 \mathrm{wt} . \%$ approximately $8 \mu \mathrm{m}$ away from the coating/oxide scale interface. The thickness of the Cr-rich reaction layer on the MC coated sample varies between $0.5-10 \mu \mathrm{m}$, with the thickest layers generally observed where the thermally grown oxide scale is thinnest and vice versa. The average reaction layer thickness was determined to $5.1 \pm 1.5 \mu \mathrm{m}$. The uneven thickness may be a result of local differences in composition after the reduction heat treatment procedure, during which the coating first is reduced to $\mathrm{MnO}$ and $\mathrm{Co}$, and then re-oxidized to $\mathrm{MnCo}_{2} \mathrm{O}_{4}$ $[32,33]$.

The trends seen in the linescan of the MC coated sample are also observed in case of the MCFe and $\mathrm{MCCu}$ coated samples, although the thickness and morphology of the different layers varies (see Figure S5 and S6 in the Supplementary material for EDX results). The extent of the reaction layer on each sample has been highlighted with a stippled line in Figure 7b)-c). The reaction layer on the MCFe and $\mathrm{MCCu}$ samples was completely absent along some portions of the interface. The average reaction layer thickness for these two samples could not be accurately determined due to a too large variation; however, the reaction layers are clearly thinner than in case of the MC coated sample.

The $\mathrm{Fe}$ content in the $\mathrm{MCCu}$ coating after oxidation at $900{ }^{\circ} \mathrm{C}$ for $2000 \mathrm{~h}$ is nearly constant throughout the whole coating and on average 5 wt.\%. I.e. the total amount of Fe in the coating does not increase during oxidation, indicating that the thermally grown oxide scale over time densified and acted as a barrier against outward diffusion of Fe from the alloy.

Table 3: Thickness of thermally grown oxide scale on spinel coated samples measured on SEM cross sections and calculated from the mass gain using Eq. 2.

\begin{tabular}{lcccccc}
\hline & \multicolumn{2}{c}{$700{ }^{\circ} \mathrm{C}(4000 \mathrm{~h})$} & \multicolumn{2}{c}{$800^{\circ} \mathrm{C}(4000 \mathrm{~h})$} & \multicolumn{2}{c}{$900^{\circ} \mathrm{C}(2000 \mathrm{~h})$} \\
\cline { 2 - 7 } & Measured & Calculated & Measured & Calculated & Measured & Calculated \\
\hline $\mathrm{MC}$ coated $[\mu \mathrm{m}]$ & $0.6 \pm 0.4$ & 1.1 & $0.6 \pm 0.4$ & 2.8 & $2.8 \pm 0.9$ & 8.3 \\
$\mathrm{MCFe}$ coated $[\mu \mathrm{m}]$ & $0.5 \pm 0.4$ & 1.1 & $0.6 \pm 0.4$ & 3.1 & $3.9 \pm 1.0$ & 8.7 \\
$\mathrm{MCCu}$ coated $[\mu \mathrm{m}]$ & $0.7 \pm 0.3$ & 1.3 & $0.9 \pm 0.6$ & 3.4 & $4.5 \pm 1.4$ & 8.7 \\
\hline
\end{tabular}



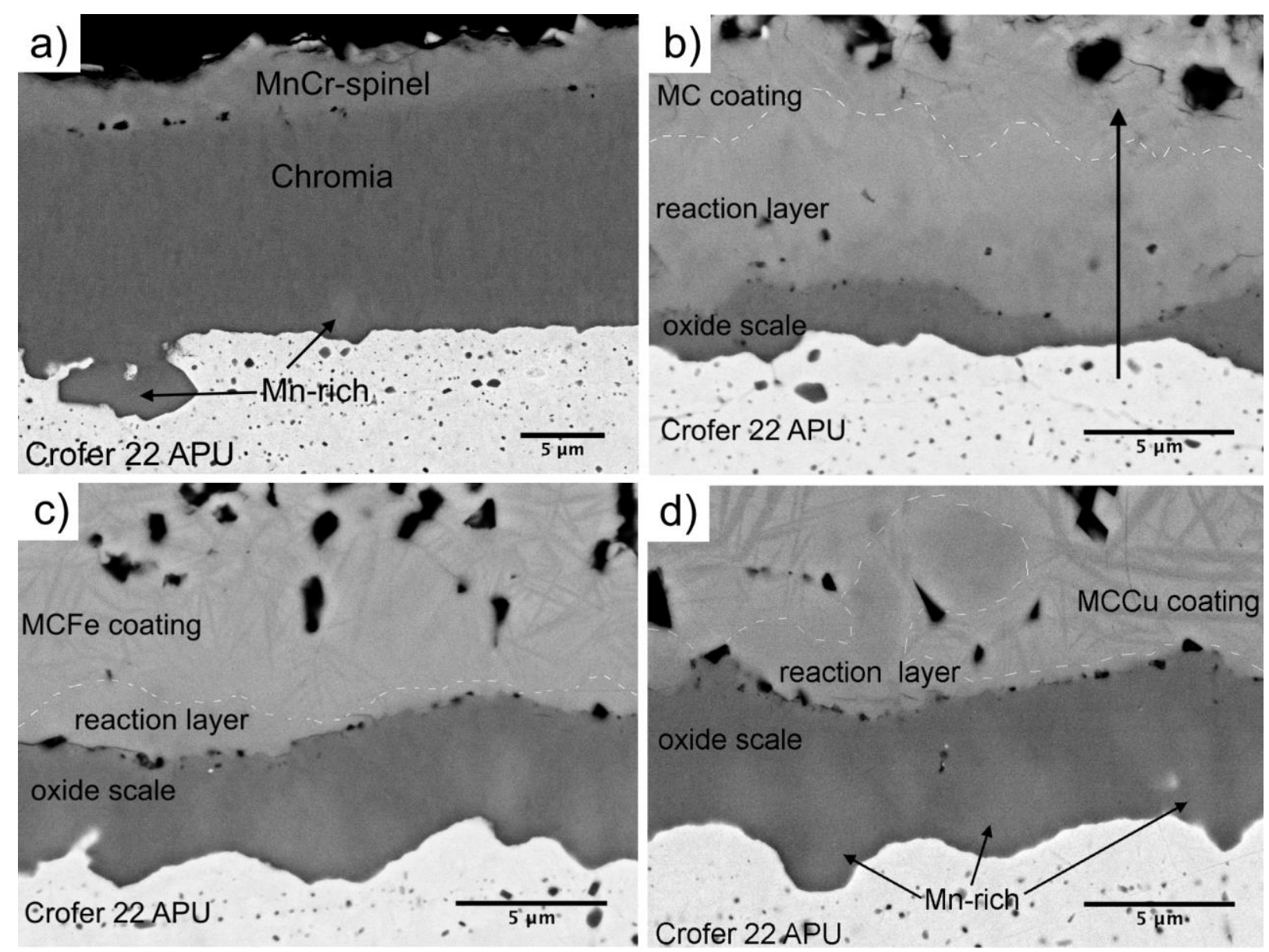

Figure 7: SEM backscatter images of spinel coated and uncoated Crofer 22 APU after 2000 h oxidation at $900{ }^{\circ} \mathrm{C}$. (a) Uncoated Crofer $22 \mathrm{APU}$ (note lower magnification), (b) MC coated (arrow shows position of EDX linescan in Figure 8), (c) MCFe coated, (d) MCCu coated. Stippled lines indicate the interface between a $\mathrm{Cr}$-containing reaction layer $(>5 \mathrm{wt} . \% \mathrm{Cr})$ and the coating.

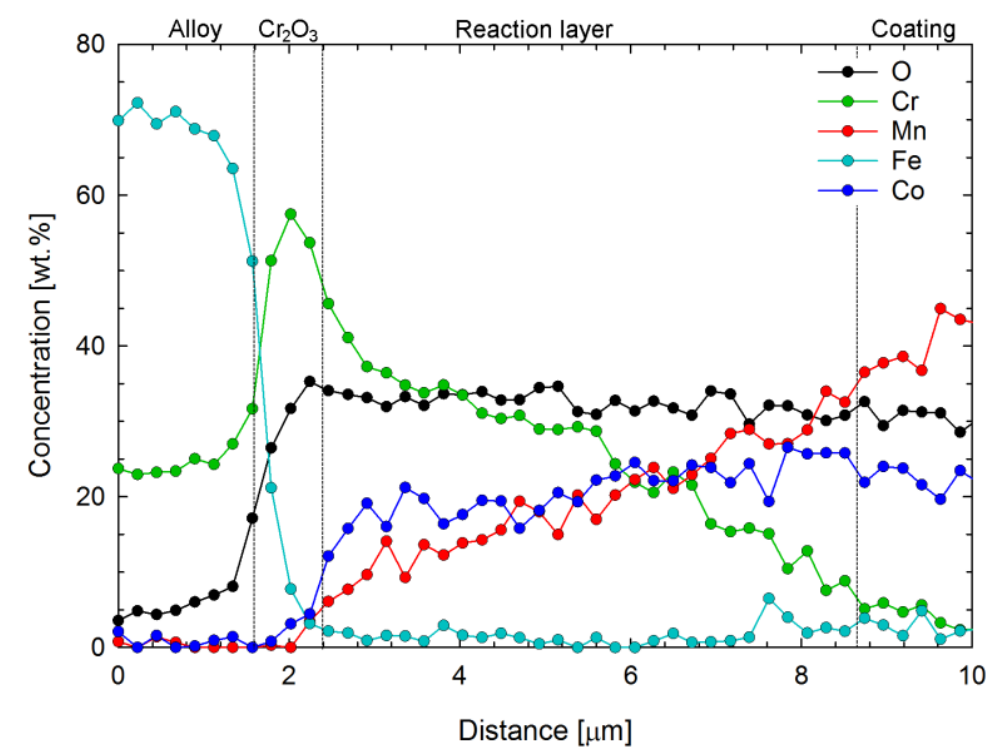

Figure 8. EDX compositional linescan across MC coated Crofer 22 APU after $2000 \mathrm{~h}$ oxidation at $900{ }^{\circ} \mathrm{C}$. The analyzed area is shown in Fig. $7 \mathrm{~b}$. 


\subsection{Growth and implications of the Cr-rich reaction layer}

The thickness of the thermally grown oxide scale on the spinel coated samples oxidized at 800 and $900{ }^{\circ} \mathrm{C}$ was significantly smaller than calculated from the mass change measurement assuming formation of pure $\mathrm{Cr}_{2} \mathrm{O}_{3}$ (see Table 3). Some of the mass gain is obviously due to internal oxidation, which however is difficult to quantify accurately. The remaining difference between the measured oxide scale thickness and the $\mathrm{Cr}_{2} \mathrm{O}_{3}$ thickness calculated based on the mass gain may be attributed to growth of the $\mathrm{Cr}$-rich $(\mathrm{Mn}, \mathrm{Co}, \mathrm{Cr})_{3} \mathrm{O}_{4}$ reaction layer. The following reaction exemplifies how a reaction between $\mathrm{Cr}$ (from the alloy or thermally grown oxide scale) and the $\mathrm{MnCo}_{2} \mathrm{O}_{4}$ spinel coating leads to mass gain:

$$
y \mathrm{Cr}+\left(\frac{3-y}{3}\right) \mathrm{MnCo}_{2} \mathrm{O}_{4}+\left(\frac{2 y}{3}\right) \mathrm{O}_{2} \rightarrow\left(\mathrm{MnCo}_{2}\right)_{\frac{3-y}{3}} \mathrm{Cr}_{y} \mathrm{O}_{4}
$$

where it for simplicity is assumed that the Co:Mn fraction remains equal to 2. Measurements of oxidation kinetics are used to both benchmark different alloys and coatings, and to estimate the lifetime of the interconnect. Regardless of whether this lifetime estimation is based on criteria of Cr-depletion from the alloy [37] or some critical oxide scale thickness [55], for the results to be reliable, all the $\mathrm{Cr}$ that goes from metallic state to oxidized state, whether found as a $\mathrm{Cr}_{2} \mathrm{O}_{3}$ scale or in the reaction layer, has to be accounted for.

The growth of $(\mathrm{Mn}, \mathrm{Co}, \mathrm{Cr})_{3} \mathrm{O}_{4}$ reaction layers has previously been studied by Wang et al. [24] using diffusion couples consisting of sintered $\mathrm{Cr}_{2} \mathrm{O}_{3}$ and $\mathrm{Mn}_{1.5} \mathrm{Co}_{1.5} \mathrm{O}_{4}$ pellets. The reaction product consisted primarily of $(\mathrm{Mn}, \mathrm{Co}) \mathrm{Cr}_{2} \mathrm{O}_{4}$ and was proposed to grow at the $\mathrm{Cr}_{2} \mathrm{O}_{3} /(\mathrm{Mn}, \mathrm{Co}) \mathrm{Cr}_{2} \mathrm{O}_{4}$ interface by diffusion of $\mathrm{Mn}$ and $\mathrm{Co}$ from the spinel pellet towards this interface. According to Wang [24], the growth rate of the $(\mathrm{Mn}, \mathrm{Co}) \mathrm{Cr}_{2} \mathrm{O}_{4}$ reaction product was parabolic with a rate constant equal to $6.9 \times 10^{-5} \mu^{2} \mathrm{~s}^{-1}$ at $900{ }^{\circ} \mathrm{C}$. This reaction rate forecasts a $22 \mu \mathrm{m}$ thick $(\mathrm{Mn}, \mathrm{Co}) \mathrm{Cr}_{2} \mathrm{O}_{4}$ layer after $2000 \mathrm{~h}$ at $900{ }^{\circ} \mathrm{C}$, which is more than four times thicker than the reaction layer measured for MC coated Crofer 22 APU in our work. The large difference could be due to different initial densities of the spinel oxide coating and the sintered pellet or due to the different $\mathrm{Cr}$-sources, i.e. a sintered $\mathrm{Cr}_{2} \mathrm{O}_{3}$ pellet vs. the oxide scale thermally grown on FSS. The oxide scale on uncoated Crofer 22 APU has been shown to grow by outward transport of cations [56,57]. Thus, the growth rate of the reaction layer on the coated alloy is most likely limited by outward transport of $\mathrm{Cr}$ from the alloy to the oxide scale/reaction layer interface. It was previously shown that a thicker $(\mathrm{Mn}, \mathrm{Co}, \mathrm{Cr})_{3} \mathrm{O}_{4}$ reaction layer is formed if the spinel coating is heat treated in a two-step reduction and re-oxidation procedure, compared to if the coating is heat treated in a oxidizing atmosphere only [38]. During heat treatment in reducing atmosphere, the spinel oxide decomposes to $\mathrm{Co}$ and $\mathrm{MnO}$, and the latter reacts with the $\mathrm{Cr}_{2} \mathrm{O}_{3}$ thermally grown on the stainless steel to form $(\mathrm{Mn}, \mathrm{Cr})_{3} \mathrm{O}_{4}$. Upon re-oxidation, $(\mathrm{Mn}, \mathrm{Cr})_{3} \mathrm{O}_{4}$ reacts with the coating, forming the $(\mathrm{Mn}, \mathrm{Co}, \mathrm{Cr})_{3} \mathrm{O}_{4}$ reaction layer, which grows with time. To determine the growth rate of the $\mathrm{Cr}$-rich $(\mathrm{Mn}, \mathrm{Co}, \mathrm{Cr})_{3} \mathrm{O}_{4}$ reaction layer the thickness will need to be measured over time on the spinel coated samples.

The EDX linescan in Figure 8 shows that the Mn fraction increases steadily from the alloy/oxide scale interface and outwards, and the EDX maps in Figure 6b show Mn depletion in the coating near the thermally grown oxide scale. Overall, the $\mathrm{Co} / \mathrm{Mn}$ fraction in the reaction layers is greater than the $\mathrm{Co} / \mathrm{Mn}$ fraction in the as-prepared coating. Cation distribution studies of $\mathrm{MnCo}_{2} \mathrm{O}_{4}$ have shown that $\mathrm{Mn}$ primarily occupies the octahedral sites in the spinel structure while the tetrahedral sites are mostly filled by $\mathrm{Co}[10,58,59]$. The distribution may be written as $(\mathrm{Co})[\mathrm{Mn}, \mathrm{Co}] \mathrm{O}_{4}$, where the round brackets designate tetrahedral sites and the square brackets designate octahedral sites. Chromium is known to have the strongest octahedral site preference among the transition metal cations $[60,61]$ and is 
consequently expected to occupy only octahedral sites, viz. (Co) $\left[\mathrm{Mn}, \mathrm{Cr}_{3} \mathrm{O}_{4}[12,59]\right.$. The higher $\mathrm{Co} / \mathrm{Mn}$ fraction in the reaction layer compared to the as-prepared coating suggests that outward diffusing $\mathrm{Cr}$ from the alloy primarily replaces $\mathrm{Mn}$ in the spinel, as expected from the site preference.

Diffusion couple experiments have indicated that doping $(\mathrm{Mn}, \mathrm{Co})_{3} \mathrm{O}_{4}$ with $\mathrm{Cu}$ or $\mathrm{Fe}$ could reduce the formation of a $(\mathrm{Mn}, \mathrm{Co}, \mathrm{Cr})_{3} \mathrm{O}_{4}$ reaction layer between the coating and alloy [24,25]. This is consistent with the results observed here for spinel coated Crofer 22 APU oxidized at $900{ }^{\circ} \mathrm{C}$, where the $\mathrm{MCFe}$ and $\mathrm{MCCu}$ coated samples displayed thinner reaction layers compared to the MC coated sample (Fig. 7). However, at $800^{\circ} \mathrm{C}$ the difference in reaction layer growth rate among the three coating materials is minimal. This indicates that the growth mechanism changes within the investigated temperature interval. Therefore, accelerating the lifetime testing of these coatings by increasing the aging temperature requires careful interpretation.

Since the electrical conductivity of spinel oxides decreases with increasing chromium content, there has been some concern that a fast growing reaction layer could have negative effects on the ASR of the interconnect $[12,24,62]$. For example, at $800{ }^{\circ} \mathrm{C}$ the electrical conductivity of $\mathrm{MnCo}_{2} \mathrm{O}_{4}$ is $89 \mathrm{~S} \mathrm{~cm}^{-1}$ [15], while the electrical conductivity of $\mathrm{Mn}_{0.5} \mathrm{Co}_{0.5} \mathrm{Cr}_{2} \mathrm{O}_{4}$ is only $0.007 \mathrm{~S} \mathrm{~cm}^{-1}$ [12]. Here, it was shown that the ASR of spinel coated samples remains low despite the formation of a reaction layer considerably thicker than the oxide scale. Based on the measured thickness of the thermally grown oxide scale formed on uncoated Crofer 22 APU (ca. $3 \mu \mathrm{m}$ ) and the ASR measured after $4370 \mathrm{~h}$ at $800{ }^{\circ} \mathrm{C}\left(\mathrm{ca} .50 \mathrm{~m} \Omega \mathrm{cm}^{2}\right)$, the electrical conductivity of the oxide scale can be estimated to $0.006 \mathrm{~S} \mathrm{~cm}^{-1}$ assuming the thermally grown oxide scale is the only contributor to the interface ASR. If the oxide scale grown on the MC coated sample has the same specific electrical conductivity, the measured scale thickness $(0.6 \mu \mathrm{m})$ corresponds to an ASR of $10 \mathrm{~m} \Omega \mathrm{cm}^{2}$. If the difference between this estimate and the measured ASR $\left(14 \mathrm{~m} \Omega \mathrm{cm}^{2}\right)$ can be attributed to resistance across the $(\mathrm{Mn}, \mathrm{Co}, \mathrm{Cr})_{3} \mathrm{O}_{4}$ reaction layer, the electrical conductivity of the ca. $3.5 \mu \mathrm{m}$ thick reaction layer formed after $4370 \mathrm{~h}$ at $800{ }^{\circ} \mathrm{C}$ is estimated to $0.09 \mathrm{~S} \mathrm{~cm}^{-1}$. In reality, the specific electrical conductivity of the oxide scale formed on coated and bare alloy is likely different due to differences in impurity/defect level, and the ASR is influenced by the contacting between the LSM plates and the oxide scale or coating. Nevertheless, these simple calculations illustrate that the thickness of the thermally grown oxide scale has a greater influence on the ASR than the thickness of the $(\mathrm{Mn}, \mathrm{Co}, \mathrm{Cr})_{3} \mathrm{O}_{4}$ reaction layer. Thus, formation of a $(\mathrm{Mn}, \mathrm{Co}, \mathrm{Cr})_{3} \mathrm{O}_{4}$ reaction layer by consumption of the chromia scale is favorable for the electrical properties of the interconnect.

\section{Conclusion}

$\mathrm{MnCo}_{2} \mathrm{O}_{4}, \mathrm{MnCo}_{1.7} \mathrm{Fe}_{0.3} \mathrm{O}_{4}$ and $\mathrm{MnCo}_{1.7} \mathrm{Cu}_{0.3} \mathrm{O}_{4}$ spinels were evaluated as protective coatings for SOFC interconnects by investigating oxidation kinetics, ASR and the interaction with Crofer 22 APU alloy. These investigations showed no beneficial effects of doping $\mathrm{MnCo}_{2} \mathrm{O}_{4}$ with $\mathrm{Cu}$ or $\mathrm{Fe}$. All of the spinel coatings reduced the parabolic oxidation rate of Crofer $22 \mathrm{APU}$ in air at $800{ }^{\circ} \mathrm{C}$ and $900{ }^{\circ} \mathrm{C}$. The protective effect of the coatings diminished with decreasing temperature and at $700{ }^{\circ} \mathrm{C}$ it was not possible to conclude if the spinel coatings effectively improved the oxidation resistance of Crofer 22 APU over the time span here evaluated $(4000 \mathrm{~h})$.

The ASR of spinel coated and uncoated Crofer 22 APU in contact with LSM was measured over $4300 \mathrm{~h}$ in air at $800^{\circ} \mathrm{C}$. All three spinel coatings resulted in a three times lower ASR than uncoated Crofer $22 \mathrm{APU}$ at the end of this measurement and prevented $\mathrm{Cr}$ diffusion into the LSM. The $\mathrm{MnCo}_{2} \mathrm{O}_{4}$ coating material resulted in the lowest final ASR value and the lowest rate of ASR increase with time. 
Based on linear extrapolation of the ASR results, Crofer 22 APU coated with any of the investigated spinel materials should ensure that the ASR remains below $50 \mathrm{~m} \Omega \mathrm{cm}^{2}$ after $40000 \mathrm{~h}$ service at $800{ }^{\circ} \mathrm{C}$.

A Cr-rich reaction layer formed between the coating and thermally grown oxide scale. The thickness of the $\mathrm{Cr}$-rich reaction layer was concluded to have minor influences on the resistance across the interconnect in comparison with the thickness of the thermally grown oxide scale.

\section{References}

[1] X. Zhang, S.H. Chan, H.K. Ho, S.-C. Tan, M. Li, G. Li, J. Li, Z. Feng, Towards a smart energy network: The roles of fuel/electrolysis cells and technological perspectives, Int. J. Hydrog. Energy. 40 (2015) 6866-6919. doi:10.1016/j.ijhydene.2015.03.133.

[2] P. Kofstad, R. Bredesen, High temperature corrosion in SOFC environments, Solid State Ion. 52 (1992) 69-75. doi:10.1016/0167-2738(92)90092-4.

[3] S. Linderoth, P.V. Hendriksen, M. Mogensen, N. Langvad, Investigations of metallic alloys for use as interconnects in solid oxide fuel cell stacks, J. Mater. Sci. 31 (1996) 5077-5082. doi:10.1007/BF00355908.

[4] W.Z. Zhu, S.C. Deevi, Opportunity of metallic interconnects for solid oxide fuel cells: a status on contact resistance, Mater. Res. Bull. 38 (2003) 957-972. doi:10.1016/S0025-5408(03)00076-X.

[5] J.J. Bentzen, J.V.T. Høgh, R. Barfod, A. Hagen, Chromium Poisoning of LSM/YSZ and LSCF/CGO Composite Cathodes, Fuel Cells. 9 (2009) 823-832. doi:10.1002/fuce.200800143.

[6] H. Yokokawa, T. Horita, N. Sakai, K. Yamaji, M.E. Brito, Y.-P. Xiong, H. Kishimoto, Thermodynamic considerations on Cr poisoning in SOFC cathodes, Solid State Ion. 177 (2006) 3193-3198. doi:10.1016/j.ssi.2006.07.055.

[7] Y. Larring, T. Norby, Spinel and Perovskite Functional Layers Between Plansee Metallic Interconnect (Cr-5 wt \% Fe-1 wt \% $\left.\mathrm{Y}_{2} \mathrm{O}_{3}\right)$ and Ceramic $\left(\mathrm{La}_{0.85} \mathrm{Sr}_{0.15}\right)_{0.91} \mathrm{MnO}_{3}$ Cathode Materials for Solid Oxide Fuel Cells, J. Electrochem. Soc. 147 (2000) 3251-3256. doi:10.1149/1.1393891.

[8] F. Smeacetto, A. De Miranda, S. Cabanas Polo, S. Molin, D. Boccaccini, M. Salvo, A.R. Boccaccini, Electrophoretic deposition of $\mathrm{Mn}_{1.5} \mathrm{Co}_{1.5} \mathrm{O}_{4}$ on metallic interconnect and interaction with glass-ceramic sealant for solid oxide fuel cells application, J. Power Sources. 280 (2015) 379-386. doi:10.1016/j.jpowsour.2015.01.120.

[9] H. Kurokawa, C.P. Jacobson, L.C. DeJonghe, S.J. Visco, Chromium vaporization of bare and of coated iron-chromium alloys at 1073 K, Solid State Ion. 178 (2007) 287-296. doi:10.1016/j.ssi.2006.12.010.

[10] H. Bordeneuve, C. Tenailleau, S. Guillemet-Fritsch, R. Smith, E. Suard, A. Rousset, Structural variations and cation distributions in $\mathrm{Mn}_{3-\mathrm{x}} \mathrm{Co}_{\mathrm{x}} \mathrm{O}_{4}(0 \leq \mathrm{x} \leq 3)$ dense ceramics using neutron diffraction data, Solid State Sci. 12 (2010) 379-386. doi:10.1016/j.solidstatesciences.2009.11.018.

[11] T. Brylewski, W. Kucza, A. Adamczyk, A. Kruk, M. Stygar, M. Bobruk, J. Dąbrowa, Microstructure and electrical properties of $\mathrm{Mn}_{1+\mathrm{x}} \mathrm{Co}_{2-\mathrm{x}} \mathrm{O}_{4}(0 \leq \mathrm{x} \leq 1.5)$ spinels synthesized using EDTA-gel processes, Ceram. Int. 40 (2014) 13873-13882. doi:10.1016/j.ceramint.2014.05.106.

[12] Y. Liu, J.W. Fergus, C.D. Cruz, Electrical Properties, Cation Distributions, and Thermal Expansion of Manganese Cobalt Chromite Spinel Oxides, J. Am. Ceram. Soc. 96 (2013) 18411846. doi:10.1111/jace.12254.

[13] T. Kiefer, M. Zahid, F. Tietz, D. Stöver, H.R. Zerfass, Electrical conductivity and thermal expansion coefficientes of spinels in the series $\mathrm{MnCo}_{2-\mathrm{x}} \mathrm{Fe}_{\mathrm{x}} \mathrm{O}_{4}$ for application as a protective layer in SOFC, Proc. 26th Risö Int. Symp. Mater. Sci. Solid State Electrochem. (2005). http://juser.fzjuelich.de/record/49205 (accessed October 29, 2014). 
[14] G.G. Xia, Z.G. Yang, J. Stevenson, Manganese-Cobalt Spinel Oxides as Surface Modifiers for Stainless Steel Interconnects of Solid Oxide Fuel Cells, ECS Trans. 1 (2006) 325-332. doi: $10.1149 / 1.2215566$.

[15] B. Talic, PhD Thesis. Metallic Interconnects for Solid Oxide Fuel Cells: High Temperature Corrosion and Protective Spinel Coatings, Norwegian University of Science and Technology, 2016. https://brage.bibsys.no/xmlui/handle/11250/2404554.

[16] V. Miguel-Pérez, A. Martínez-Amesti, M.L. Nó, A. Larrañaga, M.I. Arriortua, The effect of doping $(\mathrm{Mn}, \mathrm{B})_{3} \mathrm{O}_{4}$ materials as protective layers in different metallic interconnects for Solid Oxide Fuel Cells, J. Power Sources. 243 (2013) 419-430. doi:10.1016/j.jpowsour.2013.05.109.

[17] B.-K. Park, J.-W. Lee, S.-B. Lee, T.-H. Lim, S.-J. Park, C.-O. Park, R.-H. Song, Cu- and Nidoped $\mathrm{Mn}_{1.5} \mathrm{Co}_{1.5} \mathrm{O}_{4}$ spinel coatings on metallic interconnects for solid oxide fuel cells, Int. J. Hydrog. Energy. 38 (2013) 12043-12050. doi:10.1016/j.ijhydene.2013.07.025.

[18] Y. Liu, J.W. Fergus, K. Wang, C.D. Cruz, Crystal Structure, Chemical Stabilities and Electrical Conductivity of Fe-Doped Manganese Cobalt Spinel Oxides for SOFC Interconnect Coatings, J. Electrochem. Soc. 160 (2013) F1316-F1321. doi:10.1149/2.114311jes.

[19] Y. Xu, Z. Wen, S. Wang, T. Wen, Cu doped Mn-Co spinel protective coating on ferritic stainless steels for SOFC interconnect applications, Solid State Ion. 192 (2011) 561-564. doi:10.1016/j.ssi.2010.05.052.

[20] T. Brylewski, A. Kruk, M. Bobruk, A. Adamczyk, J. Partyka, P. Rutkowski, Structure and electrical properties of $\mathrm{Cu}$-doped $\mathrm{Mn}-\mathrm{Co}-\mathrm{O}$ spinel prepared via soft chemistry and its application in intermediate-temperature solid oxide fuel cell interconnects, J. Power Sources. 333 (2016) 145155. doi:10.1016/j.jpowsour.2016.09.136.

[21] D. Szymczewska, S. Molin, P.V. Hendriksen, P. Jasiński, Microstructure and Electrical Properties of Fe,Cu Substituted (Co,Mn)3O4 Thin Films, Crystals. 7 (2017) 185. doi:10.3390/cryst7070185.

[22] A. Holt, P. Kofstad, Electrical conductivity and defect structure of $\mathrm{Cr}_{2} \mathrm{O}_{3}$. II. Reduced temperatures $\left(<1000{ }^{\circ} \mathrm{C}\right)$, Solid State Ion. 69 (1994) 137-143.

[23] J.A. Crawford, R.W. Vest, Electrical Conductivity of Single-Crystal $\mathrm{Cr}_{2} \mathrm{O}_{3}$, J. Appl. Phys. 35 (1964) 2413. doi:10.1063/1.1702871.

[24] K. Wang, Y. Liu, J.W. Fergus, Interactions Between SOFC Interconnect Coating Materials and Chromia, J. Am. Ceram. Soc. 94 (2011) 4490-4495. doi:10.1111/j.1551-2916.2011.04749.x.

[25] C.D. Kumar, A. Dekich, H. Wang, Y. Liu, W. Tilson, J. Ganley, J.W. Fergus, Transition Metal Doping of Manganese Cobalt Spinel Oxides for Coating SOFC Interconnects, J. Electrochem. Soc. 161 (2014) F47-F53.

[26] J.W. Fergus, Synergism in the design of interconnect alloy-coating combinations solid for oxide fuel cells, Scr. Mater. 65 (2011) 73-77. doi:10.1016/j.scriptamat.2010.09.020.

[27] X. Montero, F. Tietz, D. Sebold, H.P. Buchkremer, A. Ringuede, M. Cassir, A. Laresgoiti, I. Villarreal, $\mathrm{MnCo}_{1.9} \mathrm{Fe}_{0.1} \mathrm{O}_{4}$ spinel protection layer on commercial ferritic steels for interconnect applications in solid oxide fuel cells, J. Power Sources. 184 (2008) 172-179. doi:10.1016/j.jpowsour.2008.05.081.

[28] O. Thomann, M. Pihlatie, M. Rautanen, O. Himanen, J. Lagerbom, M. Mäkinen, T. Varis, T. Suhonen, J. Kiviaho, Development and Application of HVOF Sprayed Spinel Protective Coating for SOFC Interconnects, J. Therm. Spray Technol. 22 (2013) 631-639. doi:10.1007/s11666-0129880-9.

[29] G. Chen, X. Xin, T. Luo, L. Liu, Y. Zhou, C. Yuan, C. Lin, Z. Zhan, S. Wang, $\mathrm{Mn}_{1.4} \mathrm{Co}_{1.4} \mathrm{Cu}_{0.2} \mathrm{O}_{4}$ spinel protective coating on ferritic stainless steels for solid oxide fuel cell interconnect applications, J. Power Sources. 278 (2015) 230-234. doi:10.1016/j.jpowsour.2014.12.070. 
[30] J. Xiao, W. Zhang, C. Xiong, B. Chi, J. Pu, L. Jian, Oxidation behavior of Cu-doped $\mathrm{MnCo}_{2} \mathrm{O}_{4}$ spinel coating on ferritic stainless steels for solid oxide fuel cell interconnects, Int. J. Hydrog. Energy. (2016). doi:10.1016/j.ijhydene.2016.03.051.

[31] S. Molin, P. Jasinski, L. Mikkelsen, W. Zhang, M. Chen, P.V. Hendriksen, Low temperature processed $\mathrm{MnCo}_{2} \mathrm{O}_{4}$ and $\mathrm{MnCo}_{1.8} \mathrm{Fe}_{0.2} \mathrm{O}_{4}$ as effective protective coatings for solid oxide fuel cell interconnects at $750{ }^{\circ} \mathrm{C}$, J. Power Sources. 336 (2016) 408-418. doi:10.1016/j.jpowsour.2016.11.011.

[32] N.J. Magdefrau, L. Chen, E.Y. Sun, J. Yamanis, M. Aindow, Formation of spinel reaction layers in manganese cobaltite - coated Crofer22 APU for solid oxide fuel cell interconnects, J. Power Sources. 227 (2013) 318-326. doi:10.1016/j.jpowsour.2012.07.091.

[33] L.V. Gambino, N.J. Magdefrau, M. Aindow, Microstructural effects of the reduction step in reactive consolidation of manganese cobaltite coatings on Crofer 22 APU, Mater. High Temp. 32 (2015) 142-147. doi:10.1179/0960340914Z.00000000090.

[34] D.B. Butrymowicz, J.R. Manning, M.E. Read, Fe diffusion in $\mathrm{Cu}$ and Cu-alloys, J Phys Chem Ref Data. 5 (1976) 103-149.

[35] D.R. Lide, CRC Handbook of Chemistry and Physics, CRC Press, 1992.

[36] S. Molin, M. Chen, P.V. Hendriksen, Oxidation study of coated Crofer 22 APU steel in dry oxygen, J. Power Sources. 251 (2014) 488-495. doi:10.1016/j.jpowsour.2013.09.100.

[37] P. Huczkowski, V. Shemet, J. Piron-Abellan, L. Singheiser, W.J. Quadakkers, N. Christiansen, Oxidation limited life times of chromia forming ferritic steels, Mater. Corros. 55 (2004) 825-830. doi:10.1002/maco.200303798.

[38] B. Talic, H. Falk-Windisch, V. Venkatachalam, P.V. Hendriksen, K. Wiik, H.L. Lein, Effect of coating density on oxidation resistance and $\mathrm{Cr}$ vaporization from solid oxide fuel cell interconnects, J. Power Sources. 354 (2017) 57-67. doi:10.1016/j.jpowsour.2017.04.023.

[39] N.V. Gavrilov, V.V. Ivanov, A.S. Kamenetskikh, A.V. Nikonov, Investigations of Mn-Co-O and $\mathrm{Mn}-\mathrm{Co}-\mathrm{Y}-\mathrm{O}$ coatings deposited by the magnetron sputtering on ferritic stainless steels, Surf. Coat. Technol. 206 (2011) 1252-1258. doi:10.1016/j.surfcoat.2011.08.036.

[40] S. Molin, B. Kusz, M. Gazda, P. Jasinski, Protective coatings for stainless steel for SOFC applications, J. Solid State Electrochem. 13 (2008) 1695-1700. doi:10.1007/s10008-008-0635-y.

[41] H. Falk-Windisch, J.E. Svensson, J. Froitzheim, The effect of temperature on chromium vaporization and oxide scale growth on interconnect steels for Solid Oxide Fuel Cells, J. Power Sources. 287 (2015) 25-35. doi:10.1016/j.jpowsour.2015.04.040.

[42] N.H. Menzler, I. Vinke, H. Lippert, Chromium Poisoning of LSM Cathodes - Results from Stack Testing, ECS Trans. 25 (2009) 2899-2908. doi:10.1149/1.3205855.

[43] S. Taniguchi, M. Kadowaki, H. Kawamura, T. Yasuo, Y. Akiyama, Y. Miyake, T. Saitoh, Degradation phenomena in the cathode of a solid oxide fuel cell with an alloy separator, J. Power Sources. 55 (1995) 73-79. doi:10.1016/0378-7753(94)02172-Y.

[44] M. Palcut, L. Mikkelsen, K. Neufeld, M. Chen, R. Knibbe, P.V. Hendriksen, Corrosion stability of ferritic stainless steels for solid oxide electrolyser cell interconnects, Corros. Sci. 52 (2010) 3309-3320. doi:10.1016/j.corsci.2010.06.006.

[45] A.W.B. Skilbred, R. Haugsrud, Sandvik Sanergy HT - A potential interconnect material for $\mathrm{LaNbO}_{4}$-based proton ceramic fuel cells, J. Power Sources. 206 (2012) 70-76. doi:10.1016/j.jpowsour.2012.01.101.

[46] T. Brylewski, J. Dąbek, K. Przybylski, Oxidation kinetics study of the iron-based steel for solid oxide fuel cell application, J. Therm. Anal. Calorim. 77 (2004) 207-216.

[47] P. Kofstad, K.P. Lillerud, On High Temperature Oxidation of Chromium II . Properties of and the Oxidation Mechanism of Chromium, J. Electrochem. Soc. 127 (1980) 2410-2419. doi: $10.1149 / 1.2129481$. 
[48] T. Horita, H. Kishimoto, K. Yamaji, Y. Xiong, M.E. Brito, H. Yokokawa, Y. Baba, K. Ogasawara, H. Kameda, Y. Matsuzaki, S. Yamashita, N. Yasuda, T. Uehara, Diffusion of oxygen in the scales of $\mathrm{Fe}-\mathrm{Cr}$ alloy interconnects and oxide coating layer for solid oxide fuel cells, Solid State Ion. 179 (2008) 2216-2221. doi:10.1016/j.ssi.2008.07.024.

[49] K. Kawamura, T. Nitobe, H. Kurokawa, M. Ueda, T. Maruyama, Effect of Electric Current on Growth of Oxide Scale on Fe-25Cr Alloy for SOFC Interconnect at $1073 \mathrm{~K}$, J. Electrochem. Soc. 159 (2012) B259-B264.

[50] P. Kodjamanova, Q. Fu, L. Gautier, Electric Current Effects on the Corrosion Behaviour of High Chromium Ferritic Steels, Oxid. Met. 79 (2013) 53-64. doi:10.1007/s11085-012-9325-3.

[51] J.W. Stevenson, Z.G. Yang, G.G. Xia, Z. Nie, J.D. Templeton, Long-term oxidation behavior of spinel-coated ferritic stainless steel for solid oxide fuel cell interconnect applications, J. Power Sources. 231 (2013) 256-263. doi:10.1016/j.jpowsour.2013.01.033.

[52] M. Palcut, L. Mikkelsen, K. Neufeld, M. Chen, R. Knibbe, P.V. Hendriksen, Efficient dual layer interconnect coating for high temperature electrochemical devices, Int. J. Hydrog. Energy. 37 (2012) 14501-14510. doi:10.1016/j.ijhydene.2012.07.038.

[53] S. Koch, P.V. Hendriksen, Contact resistance at ceramic interfaces and its dependence on mechanical load, Solid State Ion. 168 (2004) 1-11. doi:10.1016/j.ssi.2004.01.010.

[54] A. Kruk, M. Stygar, T. Brylewski, Mn-Co spinel protective-conductive coating on AL453 ferritic stainless steel for IT-SOFC interconnect applications, J. Solid State Electrochem. 17 (2012) 9931003. doi:10.1007/s10008-012-1952-8.

[55] W.N. Liu, X. Sun, E. Stephens, M.A. Khaleel, Life prediction of coated and uncoated metallic interconnect for solid oxide fuel cell applications, J. Power Sources. 189 (2009) 1044-1050. doi:10.1016/j.jpowsour.2008.12.143.

[56] P. Huczkowski, N. Christiansen, V. Shemet, L. Niewolak, J. Piron-Abellan, L. Singheiser, W.J. Quadakkers, Growth Mechanisms and Electrical Conductivity of Oxide Scales on Ferritic Steels Proposed as Interconnect Materials for SOFC's, Fuel Cells. 6 (2006) 93-99. doi:10.1002/fuce.200500110.

[57] L. Niewolak, D.J. Young, H. Hattendorf, L. Singheiser, W.J. Quadakkers, Mechanisms of Oxide Scale Formation on Ferritic Interconnect Steel in Simulated Low and High pO2 Service Environments of Solid Oxide Fuel Cells, Oxid. Met. 82 (2014) 123-143. doi:10.1007/s11085014-9481-8.

[58] E. Rios, J.-L. Gautier, G. Poillerat, P. Chartier, Mixed valency spinel oxides of transition metals and electrocatalysis: case of the $\mathrm{Mn}_{\mathrm{x}} \mathrm{Co}_{3-\mathrm{x}} \mathrm{O}_{4}$ system, Electrochimica Acta. 44 (1998) 1491-1497. doi:10.1016/S0013-4686(98)00272-2.

[59] A. Purwanto, A. Fajar, H. Mugirahardjo, J.W. Fergus, K. Wang, Cation distribution in spinel $(\mathrm{Mn}, \mathrm{Co}, \mathrm{Cr})_{3} \mathrm{O}_{4}$ at room temperature, J. Appl. Crystallogr. 43 (2010) 394-400. doi:10.1107/S0021889810008150.

[60] A. Navrotsky, O.J. Kleppa, The thermodynamics of cation distributions in simple spinels, J. Inorg. Nucl. Chem. 29 (1967) 2701-2714. doi:10.1016/0022-1902(67)80008-3.

[61] H.S.C. O'Neill, A. Navrotsky, Cation distributions and thermodynamic properties of binary spinel solid solutions, Am. Mineral. 69 (1984) 733-753.

[62] Z. Lu, J. Zhu, E. Andrew Payzant, M.P. Paranthaman, Electrical Conductivity of the Manganese Chromite Spinel Solid Solution, J. Am. Ceram. Soc. 88 (2005) 1050-1053. doi:10.1111/j.15512916.2005.00205.x. 